\title{
Pavel Krafl
}

\section{Provinciální synody hnězdenské církevní provincie do začátku 16. století}

Prawo Kanoniczne : kwartalnik prawno-historyczny 43/1-2, 37-78

2000

Artykuł został zdigitalizowany i opracowany do udostępnienia w internecie przez Muzeum Historii Polski w ramach prac podejmowanych na rzecz zapewnienia otwartego, powszechnego i trwałego dostępu do polskiego dorobku naukowego i kulturalnego. Artykuł jest umieszczony w kolekcji cyfrowej bazhum.muzhp.pl, gromadzącej zawartość polskich czasopism humanistycznych i społecznych.

Tekst jest udostępniony do wykorzystania w ramach dozwolonego użytku. 
PAVEL KRAFL

\title{
PROVINCIÁLNÍ SYNODY HNĚZDENSKÉ CÍRKEVNÍ PROVINCIE DO ZAČÁTKU 16. STOLETÍ
}

\begin{abstract}
I. Úvod; I.A. Prameny a literatura; I.B. Středověká polská církev; I.C. Klasifikace shromážděni. Kolokvia, sjezdy biskupů; I.D. Legátské zákonodárství (1248 - 1309); II. Provinciálni synody: II,A. Provinciální synody do počátku 14. století; II.B. Období od 2. desetileti do konce 14. stoleti; II.C. Provinciální synody první poloviny 15 . století. Trąbova kodifikace; II.D. Provinciální synody druhé poloviny 15. stoleti; III. Charakteristiky provinciálního synodálnịho života Hnězdna. Shrnutí, závěr; IV. Katalog prokázaných provinciálních synod hnězdenské církevní provincie do počátku 16. století.
\end{abstract}

\section{I. Úvod}

Významným institutem stredověkého církevního práva byla provinciální synoda. Byla shromážděním biskupủ a vyššího kléru diecézí církevní provincie (opatů, představených řádů, kapitulních prelátů či později delegátů vybraných kapitulami). Svolával ji metropolita - arcibiskup nebo prípadně jeho zástupce ${ }^{1}$. Sloužila k řešení aktuálních otázek života církevní provincie; arcibiskup na ní vydával provinciální statuta, což byl soubor ustanovení normativniho charakteru. Prostřednictvím těchto statut byla též publikována ustanovení právních norem vy̌šši právní síly - papežských dekretálů a ustanovení koncili̊, prípadně též legátských statut. Právním ustanovením, na základě něhož se započalo konání juristicky vyhraněných provinciálních synod, byl dekret 4 . lateránského koncilu (1215): „Metropolitani ad correctionem excesuum et reformationem morum singulis annis facere debent provinciale concilium, in quo statuere debent personas idoneas per singulas dioceses, quae sollicite investigent, et in sequenti concilio referant corrigenda. Et episcopi debent facere synodos episcopales singulis annis, et publicare agitata in provinciali concilio, et haec negligentes ab exsecutione officii suspenduntur."2 2 V Polsku byl synodální život na provinciální úrovni velmi bohatý. Cílem studie je shmout problematiku provinciálních synod hnězdenské církevní provincie (a na nich vydávaných provinciálních statut) do počátku 16. století; podat přehled všech známých synod.

$1 \mathrm{~J}$. B ardach, B. Leśnodorski, M. Pictrzak, Historia ustroju i prawa polskiego, wydanic czwartc, Warszawa 1997, s. 55.

${ }^{2}$ Glosa k X 5, 1, 25. 


\section{A. Prameny a literatura}

Prameny. O konání polských provinciálních synod se dozvídáme převážně $z$ diplomatického materiálu, méně již z pramenů narativních. V 13. století převažuji zmínky o synodách v listinách na nich vydaných (převážně jde o svědečné a datovací formule). Od druhé ětvrtiny 15 . století jsou hlavním pramenem zase již vydané úřední knihy katedrálních kapitul diecézí hnězdenské provincie $s$ aktovými zápisy, které nás mohou informovat o plánovaných či $\mathrm{v}$ době zápisu předpokládaných datech konání provinciálních synod, o osobách vyslaných kapitulou na synodu a případně o požitcích, které jim kapitula určila na cestu ${ }^{3}$. Ostatní diplomatický materiál obsahující zmínky o synodách (listiny) je roztroušen po dílčích edicích. $Z$ vyprávěcích pramenů jmenujme kroniku Galla Anonyma, kroniku Godysława Paska, kroniku Jana z Czarnkowa, anály krakovské kapituly, ,rocznik traski“”, katalog krakovských biskupư ${ }^{4}$, Dlugoše (Catalogus archiepiscoporum Gnesnensium a Historia Polonica) $)^{5}$. Na řadě provinciálních synod byla vydána statuta. Pro některé $\mathrm{z}$ nich použivá polská historiografie vzhledem $\mathrm{k}$ jejich významu termín kodifikace. Všechna provinciální statuta jsou již dnes vydána. Jejich nejstarší souhrné edice podali krátce po sobě Anton Zygmunt Helcel a Romualdus Hube $v$ padesátých letech minulého stoletír. Většina ze

\footnotetext{
${ }^{3}$ B. U lanow ski, Acta capitulorum nec non iudiciorum ecclesiasticorum selecta, I.-II., Kraków 1894-1902 (dále ACIE); Týž, Acta capitulorum Cracoviensis et Plocensis selecta (14381523; 1438-1525), Archiwum Komisyi Historycznej, 6, 1891, s. I-296 (dále ACCP). Rozbor pramene viz P. K rafl, Akta katedrálnich kapitul hnězdenské církevni provincie jako pramen $k$ provinciálnim synodám 15. stoleti, Revue církevního práva, 15, 2000, 1, s. 35-45.

${ }^{4}$ Pomniki dziejowe Polski (Monumenta Poloniae historica), I.- III., ed. A. B ielowsk i, Warszawa 1960-196I (dále PDP).

"Joannis Dhugosz senioris canonici Cracoviensis opera omnia, I.-XIV., ed. A. Przedziecki, Kraków 1868-1878 (dále Dlugoš). Novð̌šší edice pak Ioannis Dlugossii Annales seu cronicae incliti regni Poloniae, I.-VI., Varsaviae 1964-1973.

" Starodawne prawa polskiego ponniki poprzedzone wywodem historiczno krytycznym tak zwanego prawodawstwa wiślickiego Kazimiérza Wielkiego w texcie ze starych rękopism krytycznie dobranym, I., ed. A.Z. Helcel, Warszawa 1856, s. 329-428 (dále SPPP I.). R. Hu be, Antiquissimae constitutiones synodales provinciae Gnesnensis maxima ex parte nunc primum e codicibus manu scriptis typis mandatae, Petropoli 1859. Přchled staršich souborných tisků, nekritických cdici a tiskủ soudobých rannč-novovčkých provinciálních statut hnčzdenskć církcvni provincic viz A. Joc he r, Obraz bibliograficzno-historyczny literatury i nauk w Polsce, od uprowadzenia do niej druku po rok 1830 wiqcznie, III., Wilno 1857, s. 304-309 a Podreczna encyklopedya kościelna, t. 37-38, s. 310-311 (dále PEK). Práci s titulem Decretales summorum pontificum pro regno Poloniae et constitutiones synodorum provincialium et dioecesanarum regni euisdem ad summam collectae cum annotationibus, declarationibus, admonitionibus et additionibus ex historia, iure ecclesiastico universali et iure civili regni, editae cura et studio Z. Chodyński et E. Likowski, t. 1-3, Posnaniac 1869-1883 autoři rozčlenili podle titulů knih papežských dekretálů; u kažnćho $\mathrm{z}$ nich jsou citována ustanovení synodálních a provinciálních statut - ovšcm převážñ̌ novovčkých.
} 
statut pak byla přetištěna do edičního podniku Kodeks dyplomatyczny wielkopolski ${ }^{7}$. Z řady samostatných edicí jednotlivých statut se sluší prripomenout edici kodifikace Mikuláše Trąby (1420), kterou připravili Bolesław Ulanowski, Jan Fijałek a Adam Vetulani ${ }^{8}$.

Literatura o provinciálnich synodách a statutech Hnězdna. Již autoři 17. a 18. století se zajímali o hnězdenské provinciální synody. Ve svém přehledu papežủ podává informace o polských provinciálních synodách svolaných za pontifikátu jednotlivých papežů Szymon Starowolski9. Informace o synodách poskytl $\mathrm{v}$ přehledné tabulce Józef Andrzej Załuski ${ }^{10}$. Po polovině 19. století vznikla řada prací, jež se pokouší o syntetické shrnutí tématiky. Již edice A. Z. Helcela obsahuje historický úvod" ". Do své syntézy dějin polského soukromého práva pojal kapitolu o provinciálních synodách hnězdenské provincie Piotr Burzyński ${ }^{12}$. Kapitoly o provinciálních synodách obsáhl do své práce Michał Wiszniewski ${ }^{13}$. Samostatný článek o synodách napsal J. P. Jabczyński ${ }^{14}$. I syntetická práce Pawła Władysława Fabisze je již zastalá ${ }^{15}$, podobně nepoužitelná je populárně laděná série článků

\footnotetext{
${ }^{7}$ Kodeks dyplomatyczny wielkopolski obejmujacy dokumenta tak już drukowane, jak dotqd nie ogloszone siegajqce do roku 1400 (Codex diplomaticus Maioris Poloniae. Documenta et iam typis descripta. et adhuc inedita complemens annum 1400 attingentia), I.-V., cd. F. P i ckosiński, Poznań 1877-1908 (dále KDW).

${ }^{8}$ Statuty synodalne Wieluńsko-Kaliskie Mikolaja Traby z r. 1420, z materiałów przysposobionych przez B. Ulanowski c go uzupctnili i wydali J. Fijałck i A. Vetulani, Studia i matcriały do historii ustawodawstwa synodalnego w Polsce, $c$. 4, Kraków 1915-1920-1951.

${ }^{4} \mathrm{~S}$. St a row ols ki, Epitome conciliorum tam generalium, quam provincialium in Graeca et Latina ecclesia celebratorum, quaecunque reperiri potuerunt. Itemque vitarum Romanorum pontificum, epistolarum, decretalium et diversarum sanctionum eorum, cum chronologica et historica observatione a Simone Starovolscio, primicerio Tarnoviensi, libris XXVI. comprehensa, Romae 1653.

10 J.A. Z a łusk i, Conspectus novae collectionis legum ecclesiasticarum Poloniae (titulo Synodicon Poloniae orthodoxae) tum et aliae collectionis scriptorum ecclesiasticorum Poloniae ineditorum, Varsaviae 1774, p. 9-10. Práci Ignacy Drozdowicz, Index omnium, quae in synodis provincialibus ecclesiae Gnesnensis constituta sunt, Luccariae 1791, kterou uvádí $P E K$, 37-38, s. 312, neeviduje ani centrální katalog starých tisků Biblioteky Narodowej ve Varšavč.

"SPPP I., s. 331-342.

12 P. Burzyńsk k, Prawo polskie prywatne, I., Kraków 1867, s. 62-69.

${ }_{13}^{13}$ M. Wiszn icws ki, Historya literatury Polskiéj, II., V., Kraków 1840, 1843.

14 J.N. Jabczyński, Wiadomośc o Synodach prowincyalnych polskich i zbiorach ich Statutów, Rocznik Towarzystwa naukowcgo z Uniwcrsytctem Jagicllońskim zlaczonego, 19, 1849, 4, s. $14-53$.

is P.W. Fabis z, Wiadomość o Synodach Prowincyonalnych i Dyecezalnych Gnieznieńskich io Prawach Kościola Polskiego z dodatkiem Spisu Synodów Dyecezalnych Polskich, wydanic drugic, Kçno 1861. To samć platí i o dalši Fabiszovč knizc, ve ktcré sc dotýká tématu legátských synod: Wiadomość o legatach i nuncyuszach apostolskich w dawnej Polsce (1075-1865), wydanie drugie, Ostrów 1866.
} 
Mauryce Dzieduszyckého ${ }^{16}$. V osmdesátých letech vydal historik Tadeusz Gromnicki přehled dějin polských provinciálních synod s prìhlédnutím na činnost papežských legátů do poloviny 14 . stoletín ${ }^{17}$. Tématiku provinciálních synod nemohli opomenout ani autoři Podręcznej encyklopedye kościelnej ${ }^{18}$. Cenu a hodnotu si dodnes rozhodně zachovala stručná práce významného polského právního historika Władysława Abrahama, kterou vydal v rámci zvláštní ediční řady „Studia i materiały do historyi ustawodawstwa synodalnego w Polsce“ a kde předkládá obecné teze o charakteru polských provinciálních synod ${ }^{19}$. V polovině třicátých let vydal přehled dějin hnězdenského provinciálního synodálního života časopisecky a posléze knižně (doplněno o jednu kapitolu) Michał Morawski ${ }^{20}$. V jádru jeho pozornosti je ovšem 16. a 17. století. U př́ležitosti plenárního synodu polské církve vyšel r. 1939 Piotru Kałwovi jeho historický nástin provinciálního zákonodárství předrozborového Polska ${ }^{21}$. Poslední monografie pochází z pera Ignace Subery ${ }^{22}$. Katalogový přehled provinciálních synod hnězdenské provincie do počátku 16 . století podal $P$. $\mathrm{Krafl}^{23}$. Provinciální synody slavené za jednotlivých hnězdenských arcibiskupů zaznamenal ve svých biografiích též Jan Korytkowski ${ }^{24}$. Po obsahové stránce se synodálním statutům věnoval Jan Fijałek ${ }^{25}$, dále například Z. Pazdro ${ }^{26}$. Jednotlivým hnězdenským provinciálním synodám

\footnotetext{
${ }^{16} \mathrm{M}$. Dzied us zy cki, O synodach katolickich w dawnej Polsce, Przegląd Lwowskí, 10, 1880, s. 83-89, 151-158, 294-299, 461-469, 534-537, 718-724.

${ }^{17} \mathrm{~T}$. G ro mn icki, Synody prowincyonalne oraz czynnosici niektórych funkcyonaryuszów apostolskich w Polsce do r. 1357, Kraków 1885.

${ }^{18}$ PEK, t. 37-38, s. 310-327.

$19 \mathrm{~W}$. A b r a ham, Studya knytyczne do dziejów średniowiecznych synodów prowincyonalnych kościola Polskiego, Studya i materyaly do historyi ustawodawstwa synodalnego w Polscc, n. 5 , Krakow 1917, hlavně kapitola první: Synody prowincyonalne i zjazdy biskupskic przed kodifikacyą Mikołaja Trąby z r. 1420, s. 7-18.

${ }^{20} \mathrm{M}$. Morawski, Synod prowincjonalny prowincji Gnieżnieńskiej w dawnej Polsce, Atcncum kaplańskic (dále AK), 21, 1935, sv. 35, s. 139-163, 313-332, sv. 36, s. 1-27, 150-170. Samostatnč pod týmž titulem vyšlo ve Wrocławku 1935.

${ }^{21}$ P. K ałwa, Pierwszy polski synod plenarny wraz z orędziem episcopatu polski do duchowiensstwa $i$ wiernych $w$ sprawie uchwal tegoz synodu poprzedzony rysem historycznym prowincjonalnego ustawodawstwa synodalnego w Polsce przedrozbiorowej, Towarzystwo wiedzy chrześcijańskicj ogólnego zbioru, t. 51, Lublin 1939.

22 I. Subera, Synody prowincjonalne arcybiskupów gnieznienskich, Zarys historii prawa kościclncgo w Polscc, n. 1, Warszawa 1971.

${ }^{23} \mathrm{P}$. K rafl, Prehled provinciálnich synod Hnězdna z let 1206-1503, Slovanské historické studie, 25, 1999, s. 5-34.

${ }^{24} \mathrm{~J}$. Koryt k ow ski, Arcybiskupi gnieżnienscy, prymasowie i metropolici polsci od roku 1000 aż do roku 1821, I.- II., Poznań 1889.
} 
a statutům je věnována řada dílčích studii, ${ }^{27}$ místo je jim věnováno též v monografích jednotlivých arcibiskupů. ${ }^{28}$

\section{B. Středovéká polská cirkev}

K roku 1112, do kdy psal Gallus Anonymus, fungovala jako součást hnězdenské církevní provincie biskupství krakovské, poznaňské, vratislavské a plocké. Diecézní soustava byla dále doplněna za Boleslava Křivoústého. $Z$ jeho doby pochází první zmínky o biskupství pomořském, lubušském a włocławském. Místo zaniklého biskupství v Kolobřehu vzniklo biskupství ve Wolině (1140), které bylo r. 1188 přeneseno do Kamieńa Pomořského a podřízeno bezprostředně papeži. Křižáky založené biskupství v Chelmu (1243) se přičlenilo k arcibiskupství rižskému, které získalo metropolitní oprávnění r. 1255. Kromě zmíněnóho biskupa v Chelmu byli rižskému arcibiskupovi podř́ízeni sufragáni z Fromborku, Kwidzynu a Královce (biskupství warmiňské, pomezaaňské a sambijské). Roku 1375 získalo metropolitní oprávnění arcibiskupství haličské (zal. 1367), v r. 1414 přenesené do Lvova. Ujalo se diecézí v Přemyšli, Chelmu, Vladiměři, Kamienci, Kyjevě a Seretu (v Moldávii). Hnězdno získalo biskupství, která vznikla nově v zemích litevských: Vilnius a Miedniki. Roku 1418 obdržel hnězdenský arcibiskup hodnost primasovskou.

Spory mezi knížaty na počátku 13 . století donedávna na státu zcela závislé církvi dovolily, aby vůči němu vystoupila jako rovnocenná síla. Hlavním propagátorem reforem se stal arcibiskup Henryk Kietlicz (11991219). Byly vytvořeny základní podmínky pro realizaci postulátů 4 .

\footnotetext{
${ }^{25} \mathrm{~J}$. Fijałck, Średniowieczne ustawodawstwo synodalne biskupów polskich, I Życie i obyczaje kleru w Polsce średniowiecznej na tle ustawodawstwa synodalnego, Krakow 1893.

${ }_{26} \mathrm{Z}$. Pazdro, Lichwa w świetle ustawodawstwa synodalnego polskiego w wiekach średnich, Kwartalnik historyczny, 15, 1901, s. 449-503.

${ }^{27}$ Lze jmenovat autory W. Abrahama, M. Fąku, K. Głombiowskćho, H. Likowského, J. K. Mętlewicze, J. Nowackého, A. Vetulaniho, aj.

${ }^{28} \mathrm{~J}$. U miń sk i, Henryk arcybiskup gnieżnieński zwany Kietliczem (1199-1219). Lublin 1926; Týž, Arcybiskup Wincenty z. Nialka, nastepca Henryka, zw. Kietliczem, in: Ksiega pamiatkowa ku czci Wladyslawa Abrahama, II., Lwów 1931, s. 137-166; Wladyslaw Karasiewicz, Jakób II Świnka. Arcybiskup Gnieźnieński (1283-1314), Poznań 1948; Tadeusz Siln icki Kaz imi crz Golab, Arcybiskup Jakub Świnka i jego epoka, Warszawa 1956; Ta de us z Silnicki, Arcybiskup Mikolaj Traba. Warszawa 1954; Wladyslaw Klapkowski, Dzialalność kościelna biskupa Wojciecha Jastrebca, Warszawa 1932; Stefan Hain, Wincenty Kot, prymas polski (1436 - 1448), Poznań 1948; Henryk Rybus, Kardynal Fryderyk Jagiellończyk jako biskup krakowski i arcybiskup gnieżnieński, Warszawa 1935.
} 
lateránského koncilu (1215). Polská farní organizace měla velmi řídkou strukturu: bylo typické, že farnost zahrnovala několik či několik desítek osad. Farnosti s jednou vsí se nacházely zř́idka na západě Polska. Podle rozhodnutí 4. lateránského koncilu se měly pravidelně konat diecézní synody. Statuta kardinála Jakuba $\mathrm{z}$ roku 1248 berou jako normální věc konání diecézních synod. Každoroční synody vzpomíná též roku 1267 legát Guido, dále provinciální synoda kališská r. 1406 i kodifikace Mikuláše Trąby z r. 1420. První doloženou diecézní synodou v Polsku je synoda vratislavského biskupa Tomáše I. z r. 1256. V krakovské diecézi konal první diecézní synodu pravděpodobně Pavel z Przemankowa. Krakovský biskup Nanker v úvodu svých statut z r. 1320 vzpomíná konstituce svých předchůdců. V Plocku synodální statuta z r. 1388 vzpomínají též dřívější synodální konstituce. Počátkem 15 . století se objevily synodální statuta $\mathrm{v}$ diecézích włocławské, hnězdenské, przemyszské, lvovské a poznaňské2y .

\section{C. Klasifikace shromáždění. Kolokvia, sjezdy biskupů}

Kvalifikace shromáždéni biskupủ a prelátů. Rozlišovat budeme provinciální synody a legátské synody, které rozšiřovaly a formovaly partikulámí právo církevní provincie. Od nich musíme dále odlišit knížecí kolokvia a biskupské sjezdy, které formálněprávně synodami samozřejmě v žádném prípadě nebyly. Kolokvia neměla jednolitý charakter. Stanisław Zachorowski rozlišuje pro 13 . století sjezdy knížat, které mají rodinný či rodový charakter a na kterých knížata doprovází jejich dvorští a zemští úředníci, „mezinárodni“" sjezdy politického charakteru (resp. celopolské) a nakonec sjezdy jednotlivých knižat $\mathrm{s}$ jejich úředníky bez účasti jiných knižat. Svolávala je knížata. Kolokvií se účastnili vedle světských činitelů

${ }^{29}$ R. Grodecki, S. Zachorowski, J. Dąbrowski, Dzieje Polski średniowieczej, 1.-1l., Kraków 1995, s. 70-71, 84-85. W. A bra h a m, Organizacya kościola w Polsce do polowy wieku XII., 2. wydanic, Lwów 1893, 30-66, 88, 94-108. Zy g mund Sułow sk i, Struktura organizacji diecezjalnej kościola polskiego w wiekach średnich, in: Ksicga tysiąclccia katolicyzmu w Polsce, I., red. M. Pechow ic z, Lublin 1969, s. 76-80; A. Vetu lan i, Średniowieczny kościól polski w zasiegu lacinskiej kultury prawniczej, ibidem, s. 391-421; W. Wójci k, Kościelne ustawodawstwo partykularne w Polsce przedrozbiorowej na tle powszechnego prawodawstwa kościelnego, ibidem, s. 423-502. U. B orkowska, Odbudowa i rozwój (2. pol. XI i XII w.), in: Chrzcścijaństwo w Polsce. Zarys przemian 966-1979, red. J. Kłoczowski, Lublin 1992, s. 53-88, A. Witkowska, Przemiany XIII wieku (1198-1320), ibidem, s. 89-114, J. Kłoczowski, W dobie wielkiego rozwoju (1320-1450), ibidem, s. 115-150, E. Wiśniowski, Bilans średniowiecza (1450-1525), ibidem, s. 151-188. 
i činitelé duchovní. Předmětem jednání byly otázky organizace obrany státu, politické otázky, správa státu. Není vyhraněná hranice mezi kolokvii a biskupskými sjezdy a i v polské historiografii se lze setkat s různým označením pro jednotlivá konkrétní shromáždění. Př́ikladem může být shromáždění konané roku 1161 v Łeczyci u príležitosti vysvěcení kostela. Zachorowski píše o kolokviu, Abraham a Subera o sjezdu biskupů. Abraham $v$ jiném prípadě píše o sjezdech biskupů konaných při sjezdech knížecích, kolokviu; mnohdy se patrně konaly souběžně či spíše splývaly. Otázkou je, zda mnohá z kolokvií a biskupských sjezdů nebyla spiše neformálními shromážděními (správní záležitosti se nepřidružovaly či pouze druhotně), zda je tedy lze kvalifikovat v kategoriích správních či právních, anebo zda hlavním bodem nebyl jiný církevně-správní úkon (vysvěcení kostela, biskupa) a přitomnost ostatních činitelů (duchovních i světských), nebyla spíše společenskou záležitostí, vyplývaiící z přirozeného lidského sdružování se. Termín ,sjezd biskupư “ by pak byl implantátem novověké historiografie nebo mírněji řečeno její pomscnou berličkou, jejiž existence vyplývá pouze z prosté potřeby klasifikovat. Jaká míra formalizace provázela tato shromáždění? Měla jednání převážně správní charakter či politický? Tyto otazníky platí hlavně k ranému období (12., 13. stol.), kdy je jednak nejvíce dokladi̊ o sjezdech a kdy jednak nebyly vyhraněny správní instituce. Kusé informace pramenů nejsou dostatečnou oporou pro přesné určení charakteru shromáždění. Ve svém výkladu jsem se snažil jako provinciální synody klasifikovat toliko shromáždění, která jsou v pramenech jako synodus (provincialis, generalis apod.) označena a současně splňují podmínky definice provinciální synody $z$ hlediska účasti. Legátské synody se konaly přiležitostně; zlatým obdobím synod papežských legátů byla druhá polovina 13. století. Legátská synoda se konala pod vedením papežského legáta. Účastnit se jí byli povinni diecézní biskupové $z$ církevních provincií a diecézí, pro něž byla synoda svolána. Statuta, která na legátských synodách byla vydávána, měla vyšší právní sílu než provinciální statuta. Vzhledem $\mathrm{k}$ jejich významu pro provinciální zákonodárství budou v úvodu též zmíněna.

Kolokvia, sjezdy biskupů. Mezníkem $\vee$ polských dějinách bylo kolokvium konané roku 1180 v Lęczyci. Rozhodnutí nezabavovat majetek po zemřelých biskupech je významným krokem na emancipační cestě církve. Roku 1177 se konalo knížecí kolokvium za prítomnosti biskupů v Hnězdně. Sjezd biskupů se konal např. u př́ležitosti vysvěcení kostela jędrzejowského v letech 1174-1176, kostela v Sandoměři roku 1191, vysvěcení poznan̆ského biskupa Pawła ve Mstowě 1212. Téhož roku se 
konal sjezd v Mikulině. Roku následujícího (1213) se konal sjezd biskupů v Sieradzu. Ještě k roku 1209 je doloženo kolokvium za prítomnosti biskupů v Hlohově. $Z$ dalších let známe kolokvia ve Wiertelewě 1223 , Gąsawě 1227 a na neznámém místě konaný sjezd r. 1228. U přiležitosti konsekrace arcibiskupa Pełky se biskupové sešli na sjezdu v Łeczyci r. 1232. Roku 1250 byla na shromáždění v Sieradzu uzavřena za prostřednictví arcibiskupa Pełky a vratislavského biskupa Tomáše dohoda mezi kujavským knížetem Kazimírem a włocławským biskupem Michaelem. Kanonizace sv. Stanislava byla zase př́ležitostí ke konání shromáždění v Krakově r. 1254, jehož se měli účastnit jak biskupové, tak knížata. Tři shromáždění jsou doložena v osmdesátých letech 13. století: sjezd biskupů r. 1285 v Krakově, kolokvium r. 1286 v Lądu a biskupský sjezd za prítomnosti papežského legáta r. 1287 v Opole a Ratiboři. Při konsekraci poznaňského biskupa Jana v Sochaczowě r. 1323 je doložen též sjezd. Zmínit můžeme ještě napřiklad kolokvium Kazimíra Velikẻho z r. 1350. W Abraham za sjezdy považuje dvě shromáždění z let 1376 a 1378 , o kterých nás informuje současník Jan z Czarnkowa a Dlugoš později označil za synody. První se konal v Uniejowě, druhý v Kališsi ${ }^{30}$.

\section{D. Legátské zákonodárství (1248-1309)}

Významnou roli v rámci provinciálního zákonodárství sehrály od poloviny 13 . do počátku 14 . století legátské synody. V průběhu 13. století se v Polsku legáti objevují velmi často; Tadeusz Silnicki je nazývá ,epoką legacką“. Zatímco o legátských synodách 12 . století se dozvídáme toliko z kronikářských zpráv, ve 13. století již byla vydávána statuta. Na legátské synodě měl rozhodující slovo papežský legát. Shromáždění biskupové prijímali na vědomí statuta, která pak publikovali ve svých diecézích. Hlavním úkolem bylo seznámit místní biskupy s předpisy práva obecného, což bylo ve století zvýšené zákonodárné aktivity zvláště aktuální. Další projednávanou otázkou bývala církevní kázen̆, dodržování církevních předpisů. Řada legátı̊ jmenovaných pro Polsko pobývala ve Vratislavi. Všechny legátské synody, které se ve 13. století konaly na území Polska a z nichž vzešla statuta, zde byly slaveny. Na rok 1248 do Vratislavi svolal

\footnotetext{
${ }^{30}$ S. Zachorows ki, Studya z historyi prawa kościelnego i polskiego, Kraków 1917, s. 9-78; W. A bra ha m, Studya krytyczne, s. 13-18; 1. S ube ra, Synody, s. 35-37; P. K r a fl, Tzv. sjezdy biskupủ v Polsku vrcholného středověku, in: Církev a stát (Sbornik příspěvkủ z 4. ročníku konference), red. M. La mparter, Spisy Právnické fakulty Masarykovy univerzity v Brně, rada tcorctická, sv. 228, Brno 1999, s. 19-30.
} 
legátskou synodu Jakub, arcijáhen v Liege, pět let poté Gerhard z Pforzheimu. Roku 1267 zde svolal synodu ještě legát kardinál Guido. Ze závěru 13. a počátku 14. století jsou známy čtyři legátské synody, jejichž ustanovení byla právně závazná pro hnězdenskou církevní provincii. Všechny (z r. 1279, 1287, 1302, 1309) se konaly mimo její území.

Nejstarší ze známých legátských statut vydal legát Jakub, arcijáhen v Liege, na vratislavské synodě z 10 . října 1248 pro Polsko, Prusko a Pomořansko. Činnost legáta podpořil předchozího roku osobně papež Inocenc IV. Statuta se nedochovala v původní verzi, nýbrž ve variantě, kterou později vyhlásil legát Anselm. Jsou poměrně rozsáhlá, obsahují 26 článků dotýkajících se řady oblastí života kléru a církve. Na období 12511253 připadla legátská mise v Polsku kardinálu-knězi Hugo St. Cher. Ze zemí, které spadaly do legátovy působnosti, jmenujme kromě Polska Německo, Čechy, Moravu, Prusy, Pomoří. Do Polska Hugo vyslal jako svého plnomocníka dominikána Gerharda von Pforzheim, který na synodě ve Vratislavi roku 1253 vydal statuta, která se ovšem nedochovala. Bývalý legát Jakub z Liege byl mezitím zvolen papežem jako Urban IV. (1261). Legátem pro provincii ryžskou, hnězdenskou a salzburskou a pro Čechy s Moravou jmenoval Anselma, biskupa warmiňského (Ermeland). Díky němu se do dnešních dnů dochovalo znění článků legáta Jakuba. Anselm papeže upozornil na skutečnost, že polští biskupové zanedbávají ustanovení statut, která pro ně jako legát vydal. Papež mu v odpovědi r. 1262 zaslal 10 článků a v červnu r. 1263 zbylá ustanovení. Legát je následně vyhlásil.

$\mathrm{V}$ roce 1267 slavil ve Vratislavi synodu kardinál Guido, legát papeže Klimenta IV. Jeho legátská mise zahrnovala Dánsko, Švédsko, provincie Brémy, Magdeburg, Salzburg, Hnězdno, biskupství kamieńské a pražské. Od listopadu r. 1266 do poloviny května 1267 slavil čtyřri synody, na kterých vydal statuta: v Brémách, Magdeburku, Vratislavi a Vídni. Statuta vzešlá $z$ jeho čtyř synod jsou si podobná co do rozsahu i obsahu řešených problémů, taktéž i co do stylistiky a redakce jednotlivých ustanovení. Guidova vratislavská synoda se konala ve dnech 9. - 10. února 1267. Ustanovení $\mathrm{z}$ brémské a magdeburské synody legáta Guida tvoři asi třetinu statut, zbytek jsou nová ustanovení. Pramenem statut jsou konstituce 3. a 4. lateránského koncilu, méně již papežské dekretály (Dekretály Řehoře IX.). Ty články Guidonových statut, která jsou obsahově blízká starému polskému právu, se zabývají životem kléru, organizací a úřady církve, manželským právem a vztahem církve a kléru ke státu. Ke skupině ustanovení, u které nelze prokázat souvislost se starším polským právem, patîí početné články o židech, o ukládání berní na klérus, o stacjach. 
Legát Filip, biskup z Fermo, konal společně pro Uhry a Polsko legátskou synodu 14. záríi $1279 \mathrm{v}$ uherské Budě. Vzešla $\mathrm{z}$ ní nejrozsáhlejší ze všech legátských statut, jaká kdy byla pro polskou církevní provincii vydána. Dalším legátem, který se odhodlal slavit synodu, byl Jan Boccamazza (Bucamatius), biskup v Tusculum, legatus "per partes Alamanie, Bohemie, Dacie et Suecie regna nec non Moravie, Marthiani, Polonie, Pomeranie, Prussie, Cassubie et Livonie ac Russie ducatus". Synodu svolal do Würzburgu na 16. března 1287. Statuta neuzvhledñují polské poměry a polská historiografie pochybuje o jejich významnějším vlivu $\mathrm{v}$ polském prostoru. W. Abraham dává do souvztažnosti s legátskou synodou z 16 . března 1287 provinciální synodu hnězdenské církevní provincie z 16 . řijna téhož roku. Předposlední z řady statut vydal kardinál legát Mikuláš Boccasini, generál dominikánského řádu, biskup v Ostii a Veletri a pozdější papež Benedikt XI. Pochybnosti o tom, že Boccasini pro obě země vydal statuta, nejsou, otázkou ale zůstává, kdy a kde byla statuta vydána, a dále zda byly vydány pro Polsko a pro Uhry statuta zvlášt' či společně. Jsou známy dvě synody, které legát Mikuláš slavil: první v Budě ještě roku 1301, druhou v Prešpurku r. 1302. W. Abraham považuje za pravděpodobnější, ovšem bez prímých důkazi̊, termín druhý; upřesňuje jej na květen - červen r. 1302. Pokusil se rovněž rekonstruovat alespoň zlomky $\mathrm{z}$ ustanoveni nedochovaných statut, která byla patrně v Polsku užívána. Řadu legátských synod a statut uzavírá prešpurská synoda legáta pro Uhry a Polsko Gentilise, kardinála - kněze S. Martini in Montibus, z 10. listopadu r. $1309^{31}$.

\section{Provinciální synody}

\section{A. Provinciálni synody do počátku 14. století}

Na přelomu 12. a 13. století byl v Polsku již dvakrát ignorován princip seniorátu $(1180,1207)$. V červnu roku 1210 vydal papež Inocenc III. bulu, kterou uznává seniorátní právo. Odpovědí na bulu byl synod - sjezd, který se konal $\mathrm{v}$ posledních dnech července $\mathrm{v}$ Borzykowé. J. Umiński charakterizuje synodu jako zvednutí rukavice, kterou hodil Římu kníže Vladislav Laskonogi. V podstatě byla milníkem na cestě emancipace polské církve ${ }^{32}$. Provinciální synoda se konala současně s knížecím kolokviem, což je pro provinciální synody obecně neobvyklé a nepř́ipustné. Můžeme jen připomenout, že se konala před lateránským rozhodnutím (1215) konat pravidelně provinciální synody ${ }^{33}$. Ve dvou

${ }^{31} \mathrm{~K}$ lcgátským statutům viz pripravovaná studie $\mathrm{P}$. K rafl, Legátská statuta pro Polsko a provinciálni statuta Hnèzdna do konce 15. stoleti. 
listinách je výslovně označena jako sinodus (synodus). Zúčastnili se jí arcibiskup Henryk (1199 - 1219), poznaňský biskup Arnold, krakovský Vincencius, plocký Getko, vratislavský biskup Laurentius, włocławský biskup Ogerius a konečně lubušský biskup Laurentius ${ }^{34}$. Ale již před borzykowskou synodou se konala provinciální synoda, kterou W. Abraham časově zařadil kolem r. 1206. Dokladem jsou dvě listiny papeže Inocence III., které se zmiňují o exkomunikaci poznaňského biskupa; první je z 10. ledna 1207, druhá z r. 1211 - ta upřesňuje, že exkomunikační výrok padl „,in provinciali concilio“35.

Prvními doloženými statuty jsou statuta vydaná arcibiskupem Henrykem Kietliczem kolem roku 1217 v Kamieńu ${ }^{36}$. V kamieńských

32 J. Korytkowski, Arcybiskupi, I., s. 326 - 327; T. Gromnicki, Synody, s. 26; PEK, 37-38, s. 319; J. Uminski, Henryk, s. 72 - 74; I. Subera, Synody, s. 39; W. Abraham, Pierwszy spór kościelno-politiczny w Polsce, scparát z Rozprawy Wydziału historyczno-filozoficznego Akadcmii Umicjętności, t. 32, Kraków 1895, s. 30; M. F ąka, Synody, s. 102-103; W. Wó jcik, Kościelne ustawodawstwo partykularne, s. 449. Není jasnć, o jakou Borzykowou ci Borzykow se jedná.

${ }^{3} \times 5,1,25$.

${ }^{34}$ Kromč nich jsou ve dvou listinách vydaných na synodč, $\mathrm{z}$ nichž prvni vydal Slavoš (donace) a druhou kniže Vladislav (ta je z 29. července) jmenováni probošt krakovský Boguphalus (Boguchalus), Symon z Lęczyce, Mcingotus z Trzemeszna a hnězdenský Gregorus, děkan hnězdenský Hugo a krakovský Pctrus, arcijảhen Gcrhardus, kustos Vitus, mistr Jilji, mistr Petr ,...ct alii quam plurimi abbates, prepositi, dccani, archidiaconi, canonici, sacerdotes, clerici, et tota synodus in Boricov celebrata". KDW I., č. 66, s. 64-65 (z 29. července). Kodeks dyplomatyczny malopolski (dále KDM), II., cd. F. P i ckos ińs ki, Kraków 1886, č. 381, s. 24-25.

${ }^{35} K D W$ I., c. 59, s. 60; c. 74, s. 70-72. W. A brah a m, Studya krytyczne, s. 7; L. A b raha m, Ius canonicum, s. 409; P. Kałw a, Pierwszy polski synod plenarny, s. 10; W. Wójcik, Kościelne ustawodawstwo, s. 449. J. Korytkowski, Arcybiskupi, l., s. 331 synod časovč zar̆azuje do koncc r. 1210 či počátku r. 1211 nebo přcd r. 1210. O synodč z r. 1207 piší: J. Umiński, Henryk, s. 59 a M. Faka, Synody, s. 100-102. Oba sc odkazují na listinu vydanou r. 1208 slczským knižctem Jindřichem I. - Wilhelm Haeusler, Urkundensammlung zur Geschichte des Fürstentums Oels bis zum Aussterben der piastischen Herzogslinie. Brcslau 1883, č. 18, s. 42. $\checkmark$ piscmnosti ale není řeč o synodě ani přimo ani ncpřimo.

${ }^{36}$ Ncjnovčjší cdicc A. Vetulani, Statuty synodalne Henryka Kietlicza, Studia i matcriały do historii ustawodawstwa synodalncgo w Polscc, c. 7, Kraków 1938, s. $10-13$. Starši cdicc A. Z. Helce l, SPPP I., s. 363-364 (starší datování circiter 1271, viz s. 337); KDW I., Ł. 445, s. 391-392 (datování circiter 1271); B. Ula n ow ski, Synod prowincyonalny w Kamieniu, Studya i materyały do historii ustawodawstwa synodaincgo w Polsce, n. 2, Kraków 1915, s. 29-32. Ulanowski snaží sc dokázat, žc statuta patři do r. 1265, s. 37. Jcho závěry a popř. i datováni Helccla přckonal A. Vctulani, Statuty, s. 37 (synodu a statuta datujc prímo do r. 1217), s. 39-48 (hovoři o obdobi kolem roku 1217). Vetulani svć závčry staví na základě analýzy textu a jeho zásadních ustanovení $\mathrm{v}$ kontextu politické situace, na základĕ diplomatickćho rozboru a konečnč na základč palcografickćho rozboru Zofic Kozłowské-Budkowé, který je pripojen na konci Vctulaniho prácc (s. 39-48). I. Subcra, Synody, s. 41-43. M. Fąk a, Synody, s. 119-121. Běžně sc píšc o synodž v Kamicniu. Charakter shromážděni v Kamicniu jako provinciální synody není alc zcela prokázán - srov. l. S ubera, Synody, s. 37. 
statutech je zmínka o exkomunikačním výroku vysloveném ,in Uogbor, et in Uitouh, et in Chelou" ${ }^{\text {"37 }}$. Jedná se o Wolborz a Witow; tretí místo nebylo identifikováno. $\mathrm{V}$ těchto místech se patrně konaly provinciální synody, což nám v př́padě Wolborzu dokazuje listina z roku 1215. Zpravuje nás o rozhodčím výroku Meingota, probošta trzemeszeńského, a Gunthera, děkana $z$ Plocka, kterým rozhodli spor o desátky mezi biskupem kujavským a klášterem ve Strzelně. Za soudce sporu je určil wolborzský synod. Lze předpokládat, že se synoda konala nedlouho před vyhlášením rozhoděího výroku ${ }^{38}$. Na jedné ze svých synod se měl arcibiskup Kietlicz podle Dlugoše zabývat otázkou celibátu ${ }^{39}$.

Jednu synodu máme prokázánu u arcibiskupa Wincenty $z$ Niałka $\mathrm{k}$ roku 1226. Zpravují nás o ní Katalogi biskupów krakowskich. Místo konání je neznámé, víme toliko, že se synoda měla konat v kostele zasvěceném svatému Blažeji. Otevřel se zde konflikt mezi vratislavským biskupem a biskupem krakovským o prvenství po hnězdenském arcibiskupovi. Krakovský biskup Ivo, který argumentoval papežským privilegiem, opustil jednání synody poté, co vratislavský Laurencius odmítl ustoupit ${ }^{40}$.

Dvojí provinciální statuta se dochovala od arcibiskupa Pełky (12321258). První Pełka vydal nesporně 3. července 1233 v Sieradzu, jak dosvědčují tentokrát již dochovaná datovací formule a intitulace. Statuta obsahuji deset článků ${ }^{41}$. Existenci dalších statut Pełkových předchůdců dokazuje narace statut: ,....antecessorum nostrorum statutis..." ${ }^{\text {"42 }}$. Synoda

\footnotetext{
${ }^{37}$ A. Vetulani, Statuty, s. 12, $15-16$.

${ }^{38}$ KDW I. c. 84, s. 80. T. Gromnick i, Synody, s. 33; J. Korytkowski, Arcybiskupi, I., s. 327 (r. 1214 nebo 1215); PEK, 37-38, s. 319; M. Fąka, Synody, s. 110-112-domnívá se, že se synoda konala ještč v průbčhu roku 1215; W. A brah am, Pierwszy spór, s. 38 - píše o konci r. 1214 a počátku 1215 jako o tcrminu konáni synody; do r. 1214 či 1215 ji umístnuje i A. Vetu la ni, Statury, s. 47. J. U m iń ski, Henryk, s. 109 -dle nčj kolem poloviny roku 1215; P. Kałwa, Pierwszy polski synod, s. 10, pozn. 4; W. Wój c ik, Kościelne ustawodawstwo, s. 451.

${ }^{39}$ Dlugoš XI., s. 208.

${ }^{40}$ PDP III., s. 356. Rovnčž Dlugoš XI., s. 222 (in Historia Polonica). Srov. T. Gromnicki, Synody, s. 35-36; PEK, 37-38, s. 319; J. U mińsk i, Arcybiskup Wincenty z Nialka, nastepca Henryka, zw. Kietliczem, in: Ksiçga pamiątkowa ku czci Władysława Abrahama, II., Lwow 1931, s. 159. V pozn. 2 Umiński oponuje tvrzení starší literatury (Helcel, Korytkowski), že se synoda konala v Sulcjówč. I. Su be ra, Synody, s. 44-45. W. W ój ci ik, Kościelne ustawodawstwo, s. 452 píšc o synodč z roku 1227.

${ }^{4}$ SPPP I., s. 343 - 346; R. Hube, Antiquissimae constitutiones, s. 1-8. Srov. T. Grom nick i, Synody, s. 36-42; J. Korytkowski, Prataci, I., s. 368; Týż, Arcybiskupi, I., s. 367-368; W. A braha m. Studya, s. 1I; Týž, Ius canonicum, s. 409, 412-413; P. K ał wa, Pierwszy polski synod, s. I1; W. Wójci k, Kościelne ustawodawstwo, s. 444, 448; 1. Subera, Synody, s. 45-49. ${ }^{42}$ SPPP I., s. 343.
} 
se konala ještě tři dny poté, 6 . července, jak dosvědčuje listina, kterou tři benediktinští opati na synodě obnovují svůj spor s premonstráty předávají ho do rukou vratislavského biskupa Tomáše a dalších dvou prelátů ${ }^{43}$.

Kronika Godysława Paska, která byla sepsána v druhé polovině 13. století, věnuje odstavec další synodě arcibiskupa Pełky. Konat se měla 14. ř́jna 1257 v Lęczyci. Účastnilo se jí kromě arcibiskupa šest biskupů a další preláti. Prủběh synody ovlivnil konflikt mezi vratislavským biskupem Tomášem I. a slezským knížetem Boleslavem II. Rogatkou, na něhož byl vyhlášena kruciáta. Autor kroniky zmiňuje též „,multae etiam constitutiones in eadem synodo ... ordinatae..."44. Anály krakovské kapituly píśi o lęczycké provinciální synodě z roku 1256 . Je pravděpodobné, že se informace vztahuje $\mathrm{k}$ roku $1257^{45}$. V období episkopátu Pełky byla vydána i statuta Crescente quottidie. Nejvătší místo je v statutech věnováno trestům, které postihnou knížete a jeho zemi a jiné osoby, které zajmou biskupa. Další články první re Jakce textu obsahují ustanovení pro prípad smrti biskupa; namíreny jsou hlavně proti snahám přivlastnit si majetek zemřelého biskupa. Nedochovaly se úvodní ani závěrečné formule listiny, z kterých by bylo možno vyrozumět, kdy a kde byla vydána. Starši polská historiografie prvni redakci statutu datovala kolem $1244^{46}$ a novější redakci do roku $1257^{47}$. W. Abraham se snažil prokázat, že první verze statut náleží do roku 1257 a druhou vydal až arcibiskup Świnka r. 1287. Domnívá se, že byl vydán $\mathrm{v}$ reakci na uvěznění vratislavského biskupa Tomáše

\footnotetext{
${ }^{43}$ Kodeks dyplomatyczny klasztoru tynieckiego (dálc KDT), ed. W. Kq̨trzyńsk i, S. S molka, Lwów 1875, č. 15, s. 37: „Actum in sinodo episcoporum Polonic in Zsevor II nonas Iulii anno gratiac M.CC.XXXIII."

${ }^{44}$ PDP II., s. 581-582. Srov. J. Kory tk ow ski, Arcybiskupi. I., s. 403; K. J. He fele, Konziliengeschichte, VI., Freiburg im Breisgau 1890, s. 59; T. Silnicki, Dzieje i ustrój kościola katolickiego na Slaski do końca w. XIV. Warszawa 1953, s. 165-166.

${ }^{45} P D P$ ll., s. 806. Anály přcd informaci o synodé zmiňují k roku 1256 též včznční biskupa Tomášc, ktcrć alc trvalo do kvčtna 1257 - viz T. Siln ic ki, Dzieje, s. 165. A. Z. He l cel, SPPP I., s. 336 piše kromč o synodx̌ z r. 1257 též o synodč z r. 1256. PEK, 37-38, s. 319-320.

${ }^{46}$ R. Hube, Antiquissimae constitutiones, s. 8 datuje 1244 (zde na s. 8-10 edice); E. B rzoska, Die Breslauer Diöcesansynoden bis zur Reformation, ihre Geschichte und ihr Recht, Darstellungen und Quellen zur schlesischen Geschichte, t. 38, Breslau 1939, s. 21 -22, č. 1; J. Korytk owski, Arcybiskupi, I., s. 357 datuje 1243.

${ }^{47}$ A. Z. Helcel, SPPP I., s. 357 (edice s. 357-358). T. Gromnicki, Synody, s. 86-88. Jistě není bcz zajímavosti, žc velká ćást tohoto statutu tvoři základ pražskỷch statut arcibiskupa Jana $z$ Jenštcjna, ktcrý je vydal na synodě v řijnu $r$. 1385: Pavel Krafl, Glosa k Jenštejnovým statutủm $z$ 18. řijna 1385, Vlastivčdný včstnik moravský, v tisku.
} 
I. v ř́innu $1256^{48}$. Józef Nowacki připisuje první redakci statutu podobně jako Abraham łęczycké synodě z r. 1257 nebo shromáždění arcibiskupa Janusze ve Wrocieryżu z r. $1258^{49}$.

Největší aktivitu $\mathrm{z}$ hnězdenských arcibiskupů od druhé poloviny 13. stol. po první polovinu 14. století v oblasti synodálního zákonodárství jeví Januš (1258 - 1271) a Jakub Świnka (1283 - 1314), bezpochyby nejvýznamnější polský zákonodárce 13. století.

U arcibiskupa Januše jsou spolehlivě prokázány synody $z$ let 1258 , $1262,1267,1269$ a konečně $1270^{50}$. Na synodě sieradzské z r. 1262, byla na sv. Lamberta (17. záŕí) vydána statuta ${ }^{51}$. Zabývají se $z$ velké části otázkami desátků, jejich placení a formy jejich placení. Dalším tématem je dodržování privilegia fori. Interdikt ukládá na dvůr knížete, který udržuje kontakty s osobami postiženými klatbou. Padlo i ustanovení na ochranu pannen a vdov ${ }^{52}$. Synoda $v$ Sieradzu se konala ještě po dvou dnech, 19. zárír ${ }^{\prime 3}$. Józef Nowacki se snažil prokázat, že dne 17. září 1258 se konala provinciální synoda ve Wrocieryżu pod Pińkowem. Hlavním důkazem je mu listina vydaná arcibiskupem Januszem, biskupem krakovským Prandotou Odrowążem a vratislavským Tomášem I. na sv. Lamberta. Listina je konfirmací, do níž je inzerován testament Bogusze Mieczsławice a listina krakovského vévody Boleslava řešící spor

\footnotetext{
${ }^{48}$ W. A brah am, Studya, s. 45 - 54. Srov. M. Wy s z y ń s ki, W sprawie drugiego statutu dziesięcinnego arcybiskupa Pelki, in Ksiçga Pamiątkowa ku czci Wladysława Abrahama, Il., Lwów 1931, s. 187-197. Wyszyński má za to, žc první redakce statut vzešla ze synody slavené někdy $\mathrm{v}$ letech 1248-1257. Přcbírá závěr Abrahama, nevylučuje ale možnost, žc se synod, z kterého vzcšcl statut Crescentc quottidic, konal kolcm r. 1250, s. 191-195. Abrahamův vývod prííímá též Jakub Sawicki, Concilia Poloniae (dále CP), X., Wrocław - Warszawa - Kraków 1963, s. 49 (zde s. 328-329 ncjmodernějši edicc). W. Wójcik, Kościelne ustawodawstwo, s. 451.

${ }_{49} \mathrm{~J}$. Now ack i, Arcybiskup gnieźnieniski Janusz i nieznany synod prowincjonalny roku 1258, Przcgląd tcologiczny (dálc PT), 14, 1933, s. 162-169.

${ }^{50} \mathrm{P}$. Ka $\mathrm{ł}$ w a, Pierwszy polski synod, s. 11.

sI SPPP I., s. 358-359; R. H ube, Antiquissimae constitutiones, s. $50-53 ; K D W$ I., č. 402, s. 354-355. V úvodu statut je zminčna vedle vydavatele arcibiskupa Janušc přitomnost biskupa krakovského (Prandota), vratislavskćho (Tomáš), lubušského (Vilém), kujavského (Volimir), poznaňskćho (Bogufal). Přítomnost biskupa plockého (Pctr) dokládá list na synodě shromážděných biskupů pomořanskćmu vévodovi, M. P c rlb a ch, Pommerellisches Urkundenbuch, Danzig 1881, č. 193, s. 164.

52 Srov. T. Gromnicki, Synody, s. 102 - 107; J. Korytkowski, Prataci, I., s. 369; Týž, Arcybiskupi, I., s. 422-423; PEK, 37-38, s. 320; I. Subera, Synody, s. 52-54.

${ }^{53}$ Dokladcm je listina cistcrciáckćho opata ze Sulcjowa dotýkajicí se jcho sporu s włocławským biskupem o špitál sv. Godharda při Włocławku, B olesła w Ul a now ski, Dokumenty kujaw. skie i mazowieckie przewaźnie z XIII wieku, Archiwum Komisyi hystoryczncj, t. 4, Kraków 1888 (dále DKM), č. 28, s. 200-201. Srov. J. Now a ck i, Arcybiskup, s. 145-146.
} 
o Boguszův testament ${ }^{54} . \mathrm{V}$ datovací formuli jsou dále jmenováni probošti vratislavský, włocławský a wiślický, scholastici krakovský a włocławský, kantor hnězdenský, probošt rudzký a arcijáhni lublinský a kruszwickýss. J. Nowacki upozorn̆uje na shodu termínů provinciální synody z r. 1262 a shromáždění z r. 1258. Rovněž informace o složení účastníků - prelát̊ ze čtyř diecézí a sedmi kapitul zapadá do obrazu provinciální synody. Po legátské synodě Guida $z$ 9. února 1267 svolal Januš, jak již bylo zmíněno, provinciální synodu do Dankowa na 16. října 1267, čímž vyplnil nařízení článku Guidonových statut ${ }^{56}$. O dva roky později, r. 1269, slavil synodu v Pajęczně ${ }^{57}$. Poslední ze synod Januše se konala v Sieradzu 20. záŕí $1270^{58}$.

Daleko nejvýznamnější ze synod arcibiskupa Jakuba Świnky, s nimiž jsme seznámeni $(1285,1287,1290,1298,1306$ a 1309), byla první synoda, lęczycká z 6. ledna $1285^{59}$. K synodě jsou řazena nejrozsáhlejší statuta Świnky, která obsahují přes třicet článkủ. Statuta se dochovala ve c’ou redakcích: kratší, kterou vydal Helcel ${ }^{60}$, a širší, která je prrístupná díky edici Hubeho ${ }^{61}$. W. Abraham na základě rozboru opisů $v$ rukopisech, z nichž Hube čerpal, a na základě obsahového rozboru dokazuje, že rozšiřující dodatek Hubeho textu statut nebyl původně součástí synodálních statut

\footnotetext{
${ }^{54}$ Edice listiny viz: J. Now a cki, Nieznany dokument elekta gnieźnieńskiego Janusza z.r. 1258, PT, 13, 1932, s. 356-359.

${ }^{5} \mathrm{~J}$. Now acki, Nieznany dokument, s. 359, 365-368.

${ }^{56} K D W$ I., č. 423, s. 375, દ̌l. 11. Př́tomni byli Januš, vratislavský Tomáš I., krakovský Pavel Przcmiankowski, włocławský Volimír, poznaňský Mikuláš Lis -KDW I., č. 429, s. 379-380. Srov. T. Gromnicki, Synody, s. 130-131; J. Korytkowski, Arcybiskupi, I., s. 432-433; I. Subera, Synody, s. 54-55.

${ }^{57}$ Codex diplomaticus Silesiae (dále CDS), VII., 2, ed. Colmar Grünhagen, Breslau 1875. č. 1336, s. 178. Zdc je zmínka o synodč a místě jejim konání. CDS VII., 2, č. 1333 a č. 1334, s. 177 dokládají, žc arcibiskup Januš a mazovský biskup Petr byli v Pajçczně príitomni 16. řína, což je patrně datum konání synody. Srov. I. Subera, Synody, s. 55.

${ }^{58}$ Kodeks dyplomatyczny polski (dále KDP), II., č. 97, s. 82 - 83. Listina vydána na synodč; jmenováni jsou biskupové krakovský Pavcl, vratislavský Tomáš II., poznaňský Mikuláš, lubušský Vilém, plocký Petr, włocławský Volimír a pochopitclně arcibiskup - vydavatel listiny, ktcrá potvrzujc starši privilegia pro włocławský kostcl. Dlugoš. XI., s. 415. J. Korytkowski, Arcybiskupi, I., s. 433 - 434 (píšc ještč navíc o synodč v Kamicńu z r. 1271 - omyl); PEK, 37 - 38, s. 320; I. S u ber a, Synody, s. 55 - 56.

${ }^{59}$ Zmínka o synodč s datovánim 6. ledna je v Roczniku traskim, PDP II., s. 850 . Přitomni byli arcibiskup Jakub, krakovský biskup Pavcl z Przemankowa, poznaňský Jan, plocký Tomáš, włocławský Vislav a vratislavský Tomáš II., Urkunden zur Geschichte des Bisthums Breslau im Mittelalter, ed. Gustav Adolf Stenzel, Breslau 1845 (dále UBB), č. 129, s. 136. Srov. např. K.J. Hc fc lc, Konziliengeschichte. VI., s. 236.

${ }^{60}$ SPPP I., s. 382 - 387.

${ }^{61} \mathrm{R}$. Hube, Antiquissimue constitutiones, s. $165-180$. Přetisk s prihlédnutím k Helcclovi in $K D W$ I., c. 55I, s. $510-515$.
} 
Jakuba Świnky z roku $1285^{12}$. Několik ustanovení se týká liturgických záležitostí a svátostí. Kaplani mají farníkům vykládat v polštině Credo, Otčenáš a Zdrávas. Arcijáhnům je uložena povinnost examinování kléru prri vizitaci. Skupina článečkủ upravuje záležitosti svěcení farářů, vztah mezi farářem a jeho vikářem a opouštění diecéze beneficiáty. Konstatuje se nezbytnost zakládání nových kostelů. Ve statutech nejsou opomenuti ani Židé a veřejná bezpečnost. U ustanovení o zakládání nových klášterů a o přijímání nových členů do řeholních komunit se odráží napjatá atmosféra konfliktů mezi vratislavským biskupem Tomášem II. a slezským knižetem Jindřichem IV., na jehož stranu se postavili slezští františkáni, převážně německé národnostíi ${ }^{63}$. Již v prvním sezení lęczycké synody si vratislavský biskup stěžoval na situaci $v$ diecézi a dostalo se mu plné podpory, jak vyplývá z listiny, kterou biskupové po ukončení synody zaslali papeži Martinovi IV. ${ }^{64}$ a $\mathrm{z}$ tř́ listin vydaných arcibiskupem Jakubem ${ }^{65}$.

Další prokázaná synoda Swinky se konala v říjnu roku 1287, rovněž v Lęczyci. $Z$ notářského instrumentu, který byl vydán na třetím sezení (,tertia accione“) dne 26. ř́jna, se dozvídáme o protestu, jenž na synodě zazněl z úst plockého biskupa Tomáše, který si činil nárok na Chelmsko ${ }^{66}$. Se synodou $\mathrm{z}$ roku 1287 je rovněž v polské historiografii počínaje W. Abrahamem spojována novějši redakce zlomku Crescente quottidie ${ }^{67}$. Slezský konflikt byl v červnu 1290 ukončen privilegiem knižete Jindřicha IV. pro vratislavské biskupství. To bylo spolu s výrokem exkomunikace

\footnotetext{
${ }^{62} \mathrm{Jdc}$ o články č. 35-43, R. Hu b c, o. c., s. 178-180; KDW I., č. 551, s. 514-515 (od „In anniversario"). W. A brah a m, Studya krytyczne, s. 55-56, 57.

${ }^{63}$ Srov. T. Gromnicki, o. c., s. 193-204; I. Subera, o. c., s. 57-63; T. Silnicki, K. Goląb, Arcybiskup Jakub Swinka i jego epoka. Warszawa 1956, s. 96; W. Ka rasic wi c z, Jakób II. Świnka. Arcybiskup Gnieźnienski (1283-1314), Pracc Komisji tcologicznej, t. III, zesz. 3, Poznań 1948, s. 249.

${ }^{4} 4$ Listina vydána 15 . ledna 1285 . UBB, č. 129, s. 136-137.

6s $U B B$, c. 130, s. 137-138 (vydána tćhož dne; adresována nčkolika slezským klášterủm s výzvou k respcktovảni kladby vyhlášcnć na knižctc). UBB, č. 144, s. 151-153, pop̌r. $K D W$ I., č. 616, s. 574-575 (vydána 17. Icdna 1285; adresována třem kardinálům). $U B B$, č. 168, s. 169.

6 30 dokumentów katedry plockiej (1230-1317), cd. W. K çtr zy ńs k i, in: Sprawozdanie z czynności Zakładu Narodowego imicnia Ossolińskich za rok 1888, Lwów 1888, n. 12, s. 92. Zmíněna jc účast arcibiskupa, biskupů włocławskćho Vislava, poznańskćho Jana a plockćho Tomáše. Srov. W. Karas icw icz, Jakób II. Świnka, s. 265, 268. W. A bra ham, Studya, s. 41, 52, 57 a po nčm I. Subcra, o. c.. s. 63 piší mylnč o 16. řijnu. Již v dubnu 1287 byl vysloven predpoklad konání synody: $U B B$, c. 228, s. 227.

${ }^{67} S P P P$ 1., s. 357-358. Srovncj výšc citovanć prácc W. Abrahama, M. Wyszyńského, dálc W. Karasicwi icz, Jakób Il. Świnka, s. 268 - 270; T. Siln ick i, K. Goląb, Arcybiskup Jakub Świn$k a$, s. 96-97; I. S u be ra, o. c., s. 63; T. Sil ni ck i, Dzieje i ustrój, s. 184 - 185. Vక̌e je postaveno na úvazc o souvislosti znční statutu a kulminace slczskćho konfliktu.
} 
na porušitele ustanovení privilegia, které vydal vratislavský biskup Tomáš II., potvrzeno polskými biskupy v čele $\mathrm{s}$ arcibiskupem Jakubem na provinciální synodě v Hnězdnu 14. řijna $1290^{6 *}$. Z listiny potvrzující výměnu obcí mezi Florianem $\mathrm{z}$ Pątnova a arcibiskupem se dozvídáme o hnězdenské provinciální synodě z roku $1298^{69}$. Prostřednictvím procesu arcibiskupa proti krakovskému Janu Muskatovi víme o další synodě Jakuba Świnky ${ }^{70}$. Někdy před 2. květnem 1309 se ve Hnězdně konala posiední ze známých synod jmenovaného arcibiskupa ${ }^{71}$.

Patrně z doby Jakuba Świnky pochází několik nedatovaných zlomků statut. Kromě zmíněného Crescente quottidie je to již citovaný úsek devíti článků připojený u Hubeho $\mathrm{k}$ statutům $\mathrm{z}$ roku 1285 (c. $35-43$ ). W. Abrahamem jsou datován mezi léta 1285 a 1314 (smrt arcibiskupa Jakuba $^{72}$, W. Karasiewicz, T. Silnicki a K. Goląb jej připisuji synodě z roku $1290^{73}$. Podobně činí I. Subera. ${ }^{74}$ Dále se jedná o dva fragmenty De iniuriis clericis illatis a De anno gratiae ${ }^{75}$. A. Z. Helcel je datuje $\mathrm{k}$ synodě z r. 1290, po něm tak činí T. Gromnicki ${ }^{76}$. W. Abraham vyvozuje, že statut De anno gratiae vzešel z neznámé synody z r. 1296 anebo ze synody hnězdenské z r. $1298^{77}$. Datování statutu k r. 1298 potom přebírá W. Karasiewicz, T. Silnicki s K. Goląbem a dále I. Subera ${ }^{78}$. J. Fijałek

\footnotetext{
${ }^{6 R} U B B$, c. 254 , s. $259-262$, c. 255 , s. 260-262. Přitomni na synodẽ byli mimo jiné biskupové plocký Tomáš, włoclawský Vislav, poznaňský Jan, lubušskỷ Konrád, dále arcijáhen hlohovský Vít a kanovníci vratislavšti Scmian a Miroslav jako prokurátoři vratislavského biskupa, zástupci kapitul hnčzdenské, wlocławskć, poznaňské, lęczycké, opati z Lublina a Mohilna. PEK, 37-38, s. 320; T. Siln i ck i, Dzieje i ustrój, s. 190; W. Karas ie w i cz, Jakób II. Świnka, s. 271.

${ }^{69} \mathrm{KDW}$ II., c. 803, s. 166-167. Srov. T. Gromnicki, o. c., s. 224; W. A braham, Studya, s. 42; W. Karasie wi c z, Jakób II. Swinka, s. 271; I. Su be ra, o. c., s. 65-66.

${ }^{70}$ Synoda se muscla konat přcd 20. čcrvencem 1306. MPV Inl., č. 121, s. 78-79. W. Abraham, Studya, s. 42 datuje kolem r. 1301; W. Ka rasiew ic z, Jakób II. Swinka, s. 272 - 274 (odmítá Abrahamovo datováni k r. 1301 a datuje na koncc r. 1305 ci počátek r. 1306); 1. Subera, o. c., s. 66 bez pramenných dủkazů synodu vročil podobnč jako Karasicwicz a umístnil ji do Hnězdna. ${ }^{7}$ SPPP I., s. 389. T. G rom ni ck i, o. c., s. 233-234 (uvádí alternativy datování bud kolem roku 1309 nebo 2. kvčtna 1309). W. A braham, Studya, s. 42, pozn. 4 soudí, že se synoda konala r. 1309 s ohledem na následnou legátskou synodu Gentilise v Prešpurku. W. Karasiewicz, Jakób II. Swinka, s. 273 a I. Subera, o. c., s. 66-67 vrozil 1309.

72 W. Abraham, Studya krytyczne, s. 57.

${ }^{73}$ W. Karasie wic z, Jakób II. Swinka, s. 273 - 274; T. Silnicki, K. Goląb, Arcybiskup Jakub Świnka, s. 97, pozn. 10; bez primých dủkazi̊.

${ }^{74}$ Synody, s. $64-65$.

${ }^{75}$ SPPP I., s. 387-388; KDW II., c. 654, s. 35.

${ }^{76}$ T. Gromnicki, o. c., s. 215-216.

$\pi$ W. A braham, Studya krytyczne, s. $43-45,57$

${ }^{77}$ W. Karasiewicz, Jakób II. Świnka, s. 273-274; T. Silnicki, K. Goląb, Arcybiskup Jakub Swinka, s. 97; I. Su be ra, Synody, s. 66.
} 
a A. Vetulani statut datují 1297 s otazníkem ${ }^{79}$. Statut De iniuriis clericis illatis Abraham odmítl zařadit do Jakubovy éry; dle něj vznikl po roce 1326 a možná dokonce až po roce $1357^{80}$.

\section{B. Období od 2. desetiletí do konce 14. století}

Po Świnkově smrti zákonodárná činnost hnězdenských arcibiskupů ustala; 14 . století je ve znamení oslabení aktivity hnězdenských arcibiskupů ohledně svolávání provinciálních synod. Poměrně rozsáhlá provinciální statuta po sobě zanechal až arcibiskup Janisław (1318-1341). Vyhlásil je na provinciální synodě v Uniejowě 19. února 1326. Duchovni jsou vyzváni ke svatému životu. Je zdůrazněna imunita duchovních osob vůči světským soudům; světšti soudci nemohou před své soudy pohánět ani poddané ze statkủ duchovních. Svobodní lidé by se neměli usazovat na církevních statcích. Ustanovení se týkají též ochrany církevního majetku, ochrany před vojskem, před patrony, ochrany jeho nezcizitelnosti. Exkomunikační výrok či interdikt vyhlášený na jedince $v$ jedné diecézi se vztahuje i na diecéce ostatní. Zdůrazněna je povinnost placeni desátků. Připomenuto je nařízení Jakuba Świnky, podle něhož cizinci neznali polského jazyka nemohou obsazovat farní beneficia či učit ve školách. Farníci by neměli chodit v hrůzných maskách do kostela či na hřbitov. Nejsou opomenuti ani řádoví odpadlíci. Upozorněno je na vizitátory, kteři vyžaduji při vizitaci kostelů a farností vysoké prokurace ${ }^{81}$. „Synodyk" arcibiskupa Jarostawa. Arcibiskup Jarosław Bogoria Skotnicki (1342 - 1373), snad inspirován kodifikačním počinem krále Kazimíra Velikého, se pokusil o zpřehlednění práva hnězdenské provincie. Ve dnech 8.-10. ledna 1357 slavil v Kališi provinciální synodu. Sebral předpisy provinciálního práva vydané svými předchůdci na synodách, jmenovitě Kietlicze, Pełky, Januše, Jakuba Swinky a Janisława, dále legátů Jakuba $z$ Liege a Guida a shrnul je spolu s novými ustanoveními do svých statut. Na synodě je vydal 10. ledna; literatuře jsou známa pod označením „Synodyk Jarosława“. Dle nařizení nových statut Jarosława z 8. ledna mají biskupové ve svých diecézích a arcijáhni ve svých obvodech statuta čist a uvádět ve známost; každý správce kostela má vlastnit kopii statut.

\footnotetext{
${ }^{79}$ Statuty synodalne Wielunisko-Kaliskie, s. 211-212.

${ }^{80}$ W. A braham, Studya, s. 45 - 54.

${ }^{8}$ SPPP I., s. 397-405; R. Hube, Antiquissimae constitutiones, s. $183-204 ; K D W 11 .$, c. 1061, s. 390-298. T. Gromnicki, o. c., s. 253-263; J. Korytkows k i, Arcybiskupi, I., s. 527-529; P. Kałwa, o. c., s. 12-13; PEK, 37-38, s. 320; I. Subera, o. c., s. 67-73. Odkaz na synodu Janislawa pak nalczneme např. v listinč Nankera z r. 1340: UBB, č. 267, s. 282.
} 
Preláti ani ostatní klérus by se neměl dostavit na mši bez komže. Je upravena rezidence a obedience prelátů a kanovníků katedrálních kostelů a udělování oltár̆nictví tamtéž. U katedrálních kostelů je rozepsán pořad mši pro případ úmrtí člena kapituly či ordináře. Faráři by neměli konat denně více než jednu mši a nesmí držet konkubíny. Připomenuto je zpívání kanonických hodinek v kolegiátních kostelech. Arcijáhni a jejich zástupci nemají pobírat prokurace. Na církevních statcích by $z$ úsporných důvodů měl být toliko jeden správce. Účastníci synody jsou povinni pod hrozbou exkomunikace zachovávat tajemství synodních jednání. Statuta obsahují rovněž ustanovení proti uchvatitelům církevnich statků. Varují kleriky před zločinci. Vydavatel se nevyhnul ani chronickému konfliktu bez hranic, konfliktu mezi žebravými mnichy a farním klérem. Zbylá ustanovení se dotýkaji desátků a př́immů $\mathrm{z}$ beneficii ${ }^{82}$.

Dlugoš zaznamenal ještě k roku 1350 údajnou synodu arcibiskupa Jarosława. Měl se konat na Tři krále (6. ledna) v Kališi. Nesouhlasí ovšem jména některých údajně zúčastněných biskupư; ani v př́ipadě, že by se zmínka týkala synody $z$ roku 1357 , by výčet neodpovídal ${ }^{83}$. Dalším pramenem $z$ období episkopátu Jarosława, nad kterým visí otazník, je privilegium krále Kazimíra Velikého vydané ve věci založení vyššího soudu práva německého na krakovském hradě jako provinčního lenního soudu pro fojty a šoltyse $\mathrm{z}$ měst, jejichž pánem byl král. Bylo vydáno 5. řijna patrně r. 1356 v Krakově na shromáždění (conventio); dochováno je v potvrzení krále Vladislava Jagelonského (1421) a Vladislava III. (1444). Privilegium obsahuje mimo jiné zmínku o synodě s výčtem zúčastněných biskupů a kléru. Nelze ovšem $v$ žádném prípadě hovořit

\footnotetext{
82 SPPP I., s. 407-412; R. H u be, Antiquissimae constitutiones, s. 205 - 218; KDW III., č. 1349, s. 59-64; KDW III., č. 1350, s. 65. Z biskupů se synody účastnili krakovský Bodzantha, włocławský Matčj Golanczewski, plocký Kliment Picrzchala a poznaňský Jan Doliwa, prokurátoři vratislavskćho biskupa Przcclawa z Pogorzcli a lubušskćho biskupa Jindřicha II. von Bancz. J. Korytkowski, Arcybiskupi, 1., s. 527 - 528, 603 - 606; Týž, Pralaci, I., s. 369; T. Gro mn ic ki, o. c., s. 285-294; W. A bra h a m, Studya krytyczne. s. 11; PEK, 37-38, s. 320; M. Morawski, Synod prowincjonalny prowincji Gnieźnieńskiej w dawnej Polsce, Wrocławck 1935, s. 103-104; P. Kałwa, o. c., s. 13-14; Z. Kaczmarczyk. Monarchia Kazimierza Wielkiego. Organizacja kościola, sziuka i nauka, Poznań 1946-1947, s. 61-65; I. Subcra, o. c., s. 73-78. Jcštč před Synodykcm vytvořil Mikołaj Czcch r. 1319 soukromou sbírku polského církevního práva partikulárního; W. Wójci k, Kościelne ustawodawstwo, s. 449.

${ }^{83}$ Dlugoš XII., s. 238. Zaměnil włocławskćho Matějc za Zbiłuta a lubušskćho Apeczka von Frankcnstcin za Jana. Srovncj P. B. Gams, o. c., s. 264, 285 - 286, 345, 347, 350, 353, 355. SPPP I., s. 340; J. Kory tkow ski, Jaroslaw Bogorya Skotnicki, arcybiskup gnieżnienski, [bez bibl. údajů], s. 141-142; T. Gromnicki, o. c., s. 282; Z. Kaczmarczyk, Monarchia Kazimierza Wielkiego. Organizacja kościola, s. 62, pozn. 4.
} 
o provinciální synodě arcibiskupa Jaroslava ${ }^{84} . \mathrm{V}$ druhé polovině 14 . století synodální a se synodami spojené zákonodárné aktivity hnězdenských metropolitů utichají. Sjezdy biskupů z let 1376 a 1378 Janem z Czarnkova označené za convocatio již byly výše zmíněny ${ }^{85}$.

\section{C. Provinciálni synody prvni poloviny 15. stoleti. Trąbova kodifikace}

K dalšímu oživení činnosti provinciálních synod dochází na počátku 15. století. Synodu z roku 1402 v Lęczyci, o níž hovoři W. Abraham, nepovažuji za prokázanou ${ }^{86}$. Ve dnech 18. - 20. května 1406 ale Mikołaj Kurowski prokazatelně synodu slavil. Konala se na pozadí schizmatu, v Kališi. Obraz synody nám umožňují učinit si čtvery prameny: korespondence řimského papeže Inocence VII. s arcibiskupem Mikulášem z Kurowa před synodou, privilegium pro klášter v Trzemeszně, privilegium

${ }^{84} \mathrm{~V}$ minulosti byly dohady o datováni privilegia: 1356 ci 1365. Z. Kaczmarczyk, Monarchia Kazimierza Wielkiego. Organizacja paistwa, Poznań 1939, s. 267-268, pozn. 4; J. B ardach, B. Lcśnodorski, M. P ictrzak, Historia ustroju i prawa, s. 122, 104. F. Pickosińsk i, Przywilej króla Kazimierza Wielkiego w przedmiocie zalożenia squdu wyźszego prawa niemieckiego na zamku krakowskim. Rozprawy Wydziału historyczno-filozoficzncgo Akademii Umicjetności w Krakowic, t. 35, Kraków 1897, s. 11-17 (cdice), s. 1-10 (úvod; autor sc kloni k vročení 1356), s. 13: „....nos Kaziminus dei gratia rex Polonic ... cum reverendis in Christo patribus lamslao archiepiscopo Gneznensi, Bodzanta Cracoviensi, Sbilutho Wladislaviensi, Iohamne Poznaniensi, Nicolao Plocensi, Iohanne Lubensi episcopos, necnon abbatibus, prepositis, decanis, archidiaconis ceterisque prelatis et canonicis tam cathedralium quam collegiatarum et aliarum ecclesiarum capitulis et beneficiatis, tam secularibus, quam regularibus, exemptis et non exemptis, necnon magnificis castellanis, pallatinis, camerariis, subcamerariis, iudicibus, subiudicibus, baronibus, militibus et nobilibus, consulibus, advocatis, scabinis, iuratis civitatum, scoltetis et officialibus villarum et locorum singulorum universis, sinodum, convencionem et concilium celebramus,...”. Z. Kacz marc zyk, Monarchia Kazimierza Wielkiego. Organizacja kościola, s. 63 píšc o synodč z r. 1365. Bcz důkazů přirazuje k synodð ustanoveni „Dc his autem”, s. 65 (SPPP, I., s. 414-415). Provinciální synodu svolával a slavil toliko arcibiskup či jcho zástupcc; ncovyklé by bylo v tomto př́padě i místo konání - mimo území hnězdenské arcidiccéze.

${ }^{45} \mathrm{P}$. K rafl, Tzv. sjezdy biskupi, s. 22, 25.

${ }^{86}$ W. A braham, Studya krytyczne, s. 12 vychází z rukopisu n. 143 Jagelonské knihovny v Krakově, kde je opsán dokument z 16. prosince 1402 (Hnčzdno) týkající se kontribuce $(100 \mathrm{r}-100 \mathrm{v}$ ). $\mathbf{K}$ omylu patmč přspčl pisař, ktcrý jej nadepsal „Forma contribucionis ex statu synodali facte“. Text obsahujc zminku „Nuper in convencione generali in opido Lancicia...". Přidržímc-li se tcrminologické čistoty, nemůžcme akceptovat tezi o provinciální synodě. Termín conventio se užival pro snèmy. Srov. J. Barda c h, B. Leśn od ors ki, M. Pictrzak, Historia ustroju i prawa, s. 104. Abrahamovo tvrzení přcbirají Wladysław Klapkowski, Dzialalność kościelna biskupa Wojciecha Jastrzębca, Warszawskie studja teologiczne, n. 5, Warszawa 1932, s. 47; H. Li k ow ski, Synod prowincjonalny kaliski z.r. 1406, PT, 6, 1925, s. 378-379. Starší litcratura jcště informovala o synodě arcibiskupa Dobrogosta z r. 1400: J. Korytkowski, Arcybiskupi, I., s. 762; W. A braham, Studya krytyczne, s. 12; PEK, 37-38, s. 320. Toto tvrzení vyvrací $\mathrm{H}$. Likow ski, o. c., s. 378. 
pro kostel P. Marie v Gdaňsku, a konečně synodální statuta z 20. května. Papežem byl arcibiskup v červenci 1405 vyzván, aby svolal provinciální synod, který by zaujal stanovisko vůči schizmatu. Odpustkové privilegium pro třemešský klášter bylo vydáno na kališské synodě dne 18 . května, privilegium pro gdaňský kostel P. Marie zase 20 . května ${ }^{87}$. V úvodu statut je zmíněn Inocenc VII. jako iniciátor synody. První z ustanovení se týká vlastního synodálního života na provinciální úrovni; Mikuláš rozhodl o pravidelném svolávání provinciálních synod v třiletých intervalech a o ročním svolávání diecézních synod. Biskupové se ve svých diecézích mají starat o vizitace. Arcibiskup, který by nedodržel ustanovení, zaplatí pokutu 100 hřiven pražských grošủ, biskupové po 50 hřivnách ve prospěch metropolitní či príslušné katedrální kapituly. V krátkém ustanovení se vydavatel zastavil u svátku sv. Matěje pro př́pad, že by připadl na post. Problémem se stali rovněž falešní veřejní notářis ${ }^{88}$. Mikuláš Kurowski cyé vlastní nařizení o třiletém intervalu mezi synodami dodržel a 27. ledna 1409 slavil v Kališi provinciální synodu ${ }^{89}$. O dva roky později Kur Jwski

\footnotetext{
${ }^{87}$ A. The iner, Vetera monumenta Poloniae et Lithuaniae, I., Romae 1860, s. 776, č. 1047. H. Lik ows ki, Synod, s. 389-390. P. Sims on, Geschichte der Stadt Danzig, IV., Danzig 1913, s. 81-82, c. 119. Srov. PEK, 37-38, s. 320; H. Lik ow sk i, Synod, s. $380-384$; W. Kłapkowsk i, Dzialalność, s. 47; I. Subera, Synody, s. 83.

${ }^{88}$ Text statut je znám z originálu (jako notářský instrument) a dále pozdniho opisu, který obsahuje navic ustanovení o ohláškách: SPPP I., s. 41 5-416 (notářský instrument Benedikta Matčjova v Modły); R. Hubc, Antiquissimae constitutiones, s. 219-222 (podlc opisu). Synody pod přcdsednictvim arcibiskupa Mikulášc sc účastnili biskupové krakovský Petr Vissus Radolinski, wlocławský Jan Kropidlo, plocký Jakub z Kurdwanowa a poznaňský Vojtěch Jastrzębicc, vyslanci vratislavskćho biskupa Václava a lubušskćho Jana IV. Jmenováni jsou rovněž pomocni biskupovć: hnčzdenský Jan, krakovský Štčpán a Jan z Wloclawku; dozvídáme se dokonce o přitomnosti vladimčřskćho biskupa Řchořc, ktcrý náležcl do jurisdikce haližskćho arcibiskupa, a biskupa $z$ Vilna (Vilnius) Jakuba Plichty. $Z$ vyššiho duchovenstva lze jmenovat hnězdenského kancléřc Kclcziona, poznaňskćho kapitulniho dčkana Petra z Kobylina, włocławského kanovníka Mikulášc Wiclowicjskćho, probošta Mikulášc Strosberga, hnčzdenského kantora Petra. Srov. J. Koryt kow s ki, Arcybiskupi, I., s. 770-77I; W. A bra ha m, Studya krytyczne, s. 12; P. Katwa, o. c., s. 15; H. Likowsk i, Synod, s. 383-384, 386-389; W. Wójcik, Kościelne ustawodawstwo, s. 449; I. S ubera, Synody, s. 83-84.

${ }^{8 y}$ Listina, ktcrá mčla být vydána na synodž, jc ovšem známa $\mathrm{z}$ formulářové sbírky. Jacob Caro, Liber cancellariae Stanislai Ciolek. Ein Formelbuch der polnischen Königskanzlei aus der Zeit der husitischen Bewegung, II., Wien 1874, s. 242-243. Srov. W. A braham, Studya krytyczne, s. 12; W. A braha m, Udzial Polski w Soborze Pizańskim (1409 r.), Rozprawy Wydziału historyczno-filozoficzncgo Akademii Umicjetności w Krakowic, t. 47, 1904, s. 133-134; W. Klapkowski, Dzialalność, s. 47. Z biskupů hnězdenské provincie se zúčastnili pouze plocký Jakub, poznaňský Vojtčch a vilcnský Mikuláš. Jmenován jc dálc biskup „Johannes Ladniciensis (Laduicensis)“; Caro se mylnč domnivá, žc jde o biskupa lüttišského (cp. Laodiciensis). U synody z roku 1414 je jmenován Iohannes Leopoliensis (Jan Rzeszowski, biskup ve Lvově); o něj sc patmč jednalo-ACIE I., č. 1521, s. 321, P. B. Gams, Series, s. 351.
} 
umírá a jeho nástupce Mikuláš Trąba provinciální synodu koná až roku $1414 \mathrm{v}$ Uniejowě a to $\mathrm{v}$ souvislosti s bližicím se kostnickým koncilem ${ }^{90}$.

Kodifikace Mikuláše Trąby. Synodyk Jarosława Bogorii Skotnického nezůstal ojedinělým počinem kodifikačního rázu. Jeho následovníkem v usilování o novou kodifikaci partikulárniho práva hnězdenské církevní provincie se stal metropolita Mikuláš Trąba (1412 - 1422). Na rok 1413 přpadají první kroky ve věci zamýšlené kodifikace práva: papež Jan XXIII. na prosbu arcibiskupa vydal 24. srpna 1413 bulu, kterou svolil ke kodifikačním pracem. Významné bylo, že arcibiskup mohl díky papežově souhlasu oproti Skotnickému zrevidovat rovněž legátská statuta. Po zvolení Martina V. usiloval Trąba o schválení práce na nové kodifikaci též od tohoto papeže; stalo se tak 7. ledna $1418^{91}$. Arcibiskup na jednání metropolitní kapituly rozhodl o svolání provinciální synody do Wieluně na 13. ledna 1420. Hnězdenská kapitula své zástupce na synodě vybavila dietou ve výši šesti hřiven"2 ${ }^{\text {2 }}$ Na synodě, jíž se účastnili kromě dalších prelátů a zástupců kapitul biskupové krakovský Vojtěch Jastrzębiec, plocký Jakub z Kurdwanówa, poznaňský Ondřjej Laskary Goslawicki a vilenský Mikuláš I., byla projednávána ustanovení pro nový soubor. Pro náročnost úkolu byla synoda odročena na 15 . zárí do Kališe, kde byla nová kodifikace tentokrát pouze za přitomnosti krakovského, plockého a poznaňského biskupa vyhlášena (25. září) ${ }^{93}$. Kodifikace je oproti Synodyku již

\footnotetext{
${ }^{9}$ ACIE I., č. 1521, 1523, s. 321-323 (listiny krále Vladislava a hnčzdenskć kapituly z 30. zár̆i a 21 . rijina). Účastnili sc vodlc Trąby arcibiskup lvovský Jan, krakovský biskup Vojtěch, plocký Jakub a lubušský Jan. T. Sil n ick i, Arrybiskup Mikolaj Traba, Warszawa 1954, s. 180, 194 pišc o diecézni synodz. Arcidiccézni synodou byla i pro M. Morawskćho, o. c., s. 104. Synoda se bezpochyby konala přced 30. zárím, kdy byla vydána prvni z výše citovaných listin. W. Kłapkowsk i, Dzialalność kościelna, s. 50 datujc $\mathrm{k}$ čcrvenci či $\mathrm{k}$ čcrvnu, zcela určitč sc dle nčj konala před 5 . srpnem. Jakub Sawicki, $C P$ V., s. 44 s odkazcm na Klapkowskćho přiřadil synodu k prvnim dnüm června. J. Korytk owski, Arcybiskupi, II., s. 18-19; PEK, 37-38, s. 320; I. S ubera, o. c., s. $84-85$. ${ }^{9}$ Statuty synodalne Wielunisko-Kaliskie, s. 3-7. T. S i I n i ck i, Arcybiskup Mikotaj Traba, s. 93-94. ${ }^{92} A C I E$ I., č. 1552,1558 , s. 328-329. Počty zástupcủ katedrálních kapitul na provinciálních synodách s údaji o dietách viz P. K rafl, Akta katedrálních kapitul, s. 42.

${ }_{93}$ Statufy synodalne Wieluiskko-Kaliskie, s. 2, 120-121. Kromč prelátů prítomných na synodẽ, ktcř́i jsou vyjmenováni v závčru statut, jsou dále známi zástupci hnčzdenské kapituly na synodě: $A C I E$ I., č. 1564, s. 330. M. W is zn icw sk i, Historya literatury polskiej, V., s. 76; J.K. Mętlew icz, O synodach tęczyckich. Wiadomość historyczna do dziejów kościola, Pamiętnik religijno-moralny (dále PRM), 2l, 1851, s. 381-392; K.J. He fele, Konziliengeschichte, VIII., Freiburg im Breisgau 1887, s. 12; J. Kor y tk ow s k i, Arcybiskupi, Il., s. 62, 64-66; W. A brah am, Statuta synodu prowincjonalnego $w$ Kaliszu $z r$. 1420, Rozprawy i sprawozdania z posiedzeń Wydzialu Historyczno-Filozoficzncgo Akademii Umicjętności, t. 22, 1888, s. 88-89; PEK, 3738, s. 320; W. Kłapkowski, Dzialalność, s. 55; M. Morawski, Synod prowincjonalny, s. 104-106; P. Kalwa, o. c., s. 16 - 17; T. Siln i ck i, Arcybiskup Mikolaj Trqba, s. 93-94, $193-$ 195; I. S u be ra, o. c., s. 85-86. Na kališskć synodx̌ byl mimo jiné scpsán stižný list Bonifáci IX. ve věci plockćho probošta Sassina, který za podpory mazovského knížete Semovíta neoprávněně užival statků plocké kapituly: $A C C P$ C. 615, s. 158-160.
} 
systematicky usporádána; materiál celkem 67 článků je rozdělen do pěti knih. Jednotlivé knihy statut odpovídají obsahově knihám dekretálů Řehoře IX.: lze vysledovat strukturu vyjádřenou slovy iudex, iudicium, clerus, connubia, crimen. Statuta mají charakter výlučný. Nejvýznamnějšími prameny, jež při tvorbě kodifikace byly využity, jsou pochopitelně provinciální statuta Trąbových předchůdců, potažmo papežských legátů Pełky, Jakuba z Liege, Januše, Guida, Kietlicze, Filipa z Fermo, Swinky, Gentilise, Janisława, Skotnického, Kurowského. Byla vypuštěna ustanovení, která měla více charakter liturgický než právni, a celá řada prriležitostných statutů. $\mathrm{V}$ souvislosti se změnou postavení arcijáhnů vzala za své mimo jiné i mnohá starší ustanovení dotýkající se jejich práv. Nové podoby dále např́ílad nabyla ustanovení o právu patronátním a o manželství. Mezi použitými prameny nechybí pochopitelně papežské dekretály. W. Abraham považuje za pravděpodobné, že vydavatel měl v rukou rovněž pražská provinciální statuta Arnošta z Pardubic z roku 1349 a statuta dalších církevních provincii ${ }^{94}$. Je známo celkem 35 rut.opisů s opisy kodifikace. Kromě území dnešního Polska (zde je největší koncentrace ve Vratislavi) je lze nalézt v Mad'arsku, Německu, na Ukrajině a v Česku. O významu Trąbovy kodifikace vypovídá i skutečnost, že byla na provinciální synodě ve Lvově roku 1440 promulgována i pro lvovskou církevní provinciii ${ }^{95}$.

V březnu 1422 zaslal hnězdenskému arcibiskupu papež Martin $V$. bulu, v níž jej vyzývá ke konání provinciální synody. Trąba na schůzce s biskupem krakovským a plockým rozhodl o termínu 24. srpna 1422 a Lęczyci jako místě konáni ${ }^{96}$. 11. srpna určila hnězdenská kapitula své zástupce pro synodu a vybavila je dietou ${ }^{97}$. Dále se dochovala nedatovaná

\footnotetext{
${ }^{4}$ Statuty synodalnc Wicluńsko-Kaliskic, s. 1-121 (cdicc), s. 132 - 135. Starší cdicc: Starodawne prawa polskiego pomniki, IV., ed. Udalricus Heyzmann, Kraków 1875, s. 173-261. W. A brah a m, Statuta synodu prowincjonalnego w Kaliszu, s. 91-122; P. Kałwa, o. c., s. 17; T. Siln ick i, Arcybiskup Mikolaj Traba, s. 193-195; I. Subera, o. c., s. 87 - 88.

${ }^{95}$ Statuty synodalne Wiclunsko-Kaliskic, s. XXX-CXXXI; A. Ve tul a ni, Wroclawskie rękopisy statutów Mikolaja Traby, Sprawozdania Wroclawskicgo Towarzystwa Naukowcgo, 3, 1948, s. 251-253; K. Głombiowski, Nieznany ślqski rękopis statutów Mikołaja Truby, Wrocław 1951; M. Morawski, o. c., s. 105. O vlivu Trąbových statut na diccćzni zákonodárství z let 1423-1427 psal S. Zachorowsk i, Studya z historyi prawa, s. 98-101, 124-132, 134-148.

${ }^{96} \mathrm{~B}$. Ul a now $\mathrm{s} \mathrm{i}$, ,. Modus inquirendi super statu ecclesiae generalis " z pierwszej polowy XV stulecia, Archiwum Komisyi historycznej, 5, 1888, s. 214-215. S. Zachorow sk i, Studya z historyi prawa, s. 138-140; P. Kałwa, o. c., s. 19. Ulanowski se synodou spojil i püvod instrukce pro vizitaci „Modus inquirendi“", což odmítá W. Klapkowski, Dzialalność, s. 56, pozn. 5, s. 63, před ním Z. L i s i c k i, recenze na citovanou práci Ulanowského, in: KH, 2, 1888, s. 611 . ${ }^{97}$ Povčřcni byli dčkan, arcijáhen, scholastik a jeden člen kapituly bez bližšího určcní, patme tedy kanovník. Dicta byla tentokrát ve výši osmi hřiven, $A C I E$ I., è. 1575, s. 332.
} 
papežská písemnost určená nejmenovanému hnězdenskému arcibiskupovi, která se zmiňuje o provinciální synodě odbyté v Lęczyci. Papež s povděkem přijímá rozhodnutí krále Vladislava a litevského velkoknižete Vitolda nepodporovat české heretiky a odvolat $\mathrm{z}$ Čech Zikmunda Korybuta. Písemnost musela vzniknout mezi prosincem 1422 a březnem 1423 , tedy $v$ období ohraničeném odvoláním Korybuta Vitoldem a jeho odchodem $\mathrm{z}$ Čech. Zmínka o synodě se může vztahovat $\mathrm{k}$ lęczycké synodě z roku 1422; za nepravděpodobné považuji tvrzeni W. Kłapkowského, podle něhož se informace vztahuje $\mathbf{k}$ nějaké další synodě, která se měla konat roku $1423^{98}$. Husitské nebezpečí, reforma a papežem nařizená kontribuce byly bezprostředními př́činami svoláni další lęczycké synody. Dochoval se text listiny, kterou arcibiskup Wojciech Jastrzębiec (1423 - 1436) vyzval k účasti na synodě stanovené na 1 . května 1425 biskupa plockého. Impuls vyšel opět ze strany papeže, který hnězdenskému arcibiskupovi připoměl vizitační povinnost metropolity ${ }^{99}$ Z rukopisných zmínek jsme informováni, že arcibiskup na synodě 6. května revidoval ustanovení De poenis Trąbovy kodifikace $^{100}$. Přes pět následujících let prameny o synodách mlčí. Další provinciálni synoda se konala někdy před vydáním mandátu arcibiskupa Jastrzębce v Lęczyci 19. března 1430 (včetně) adresovanému

\footnotetext{
${ }^{98}$ B. Ula nowski, Modus inquirendi, s. 216; dokument datuje 1423. František Michálek Bartoš, Kniže Zikmund Korybutovič v Čechách, Sborník historický, 6, 1959, s. 187-188; Československé déjiny v datech, Praha 1986, s. 135; F. Šmahel, Husitská revoluce, Ill., Praha 1993, s. 131-132. Poprvé se o synodě z r. 1423 pỉ̌e bez odkazu na prameny in Compendium annalium ecclesiasticum, Odorici Raynaldi Tarvisini, congregationis oratorii presbyteri, 1. XVIII. Incipiens ab anno 14I7, perveniens usque ad annum 1478, cum intermixtis elogiis. Continuatore P. Eustachio Janka, Vetero Pragae 1726, p. 34. J. Korytk ow sk i, Arcybiskupi, II., s. 94-95; M. Wisznie wski, Historya, V., s. 83; PEK, 37-38, s. 320. W. Kłapkowsk i, Dzialalnośćc, s. 58, 60 sc snaži údajnou synodu z r. 1423 bližc časovč určit mezi polovinu srpna (nástup Jastrzçbce do Hnčzdna po smrti Trąby) a konec řijna 1423 (dlc nèj návrat Korybuta z Čech).

${ }^{99}$ J. Kory tk ow ski, Arcybiskupi, II., s. 97-98, pozn. 7, s. 98 - 99, pozn. 1, s. 99-100; ACIE II., c. 189, s. 60-63. Hnčzdenská kapitula vybavila své zástupce, arcijảhna a tři kanovníky, dietami ve výši tři hřiven: $A C I E$ I., đ. 1597, s. 338. Dlugoš XIII., s. 333-334. PEK, 37-38, s. 320-321.

${ }^{100}$ Heinrich Friedrich Jacobs on, Geschichte der Quellen des katholischen Kirchenrechts der Provinzen Preussen und Posen, mit Urkunden und Regesten, Königsberg 1837, s. 58-59, 84; L. Fin kel, Bibliografia historii polskiej, II., Warszawa 1956, s. 1468, č. 29280; A. Bl umenst ok, Wiadomość o rękopisach prawno-historycznych biblioteki cesarskiej w Petersbusgu, Kraków 1891, s. 37; Statuty synodalne Wieluńsko-Kaliskie, s. CLXIX - CLXX. Srov. W. Kłapkow ski, Dzialalność, s. 60-62. K synodě dále zastaralá studic Józef K. M̨̨tlewicz, Synod tęczycki, a 23 z porzqdku wszystkich z roku 1425, PRM, 28, 1855, s. 57-79 a I. S u be ra, o. c., s. 89-91. Těžko ríci, zda synoda trvala šest dnů (připadnč více) ncbo zda byl jcjí začátck dodatečnč posunut.
} 
vratislavskému biskupovi Konrádovi. Jak se z mandátu dozvídáme, lęczycká synoda se pokusila inovovat velkopáteční ceremonie, ohledně nichž panovaly $\mathrm{v}$ provincii zmatky a objevovaly se dokonce dogmatické chyby ${ }^{101}$. Po 17 . listopadu 1431 se konala synoda, možná v Uniejowě. Její provinciální charakter není ale plně prokázán ${ }^{102}$. V aktech kapituly poznaňské jsou $\mathrm{z} 3$. a 10 . března 1433 zmínky o vyslání představitelů na provinciální synodu do Lęczyce a $\mathrm{z} 28$. března o odvolání požitkủ pro preláty a kanovníky předtím ustavené $\mathrm{k}$ sepsání ustanovených článkủio3 . Dne 28. dubna 1435 hnězdenská kapitula delegovala děkana, kantora, scholastika, oficiála a ještě jednoho kanovníka na provinciální synodu, která se má konat v Kališi, o několik dnů později, 4. května, zase poznaňská kapitula delegovala děkana a kanovníka na provinciální synodu údajně v Lęczyci. Dlugoš hovoří o lęczycké synodě z 26. května ${ }^{104}$.

Následující sérii provinciálních synod slavil Jastrzębcův nástupce v arcibiskupském úradě Wincenty II. Kot (1436 - 1448). Konaly se v napjatém ovzduši po detronizaci Evžena IV. a volbě Felixe V. na basilejském koncilu. První z řady synod byla svolána na sv. Vojtěcha (23. dubna) 1440 opět do Lęczyce. Téhož roku se měla konat ještě provinciální synoda v Lęczyci na sv. Hedviku (15. řijna) ${ }^{105}$. Další provinciální synoda Kota se slavila v Lęczyci od 8. kvĕtna 1441. Zástupci

${ }^{101} C P$ X., s. 126-127. W. Kłapkowsk i, Dzialalnośc, s. 65 - 66 zmínku vztahuje ke konci roku 1429 ci k zaćátku r. 1430; I. Subcra, o. c., s. 91 - 92; K. Dol a, Zwiqzki diecezji wrocławskiej $z$ metropoliq gniezinien'ska $w$ latach 1418-1520, Studia theologica varsaviensia, 15, 1977, n. 1, s. 176.

${ }_{102} A C I E$ I., č. 63, s. 12: poznañská kapitula delcguje probošta (to byl mimochodem Wojciech Jastrzçbicc, přibuzný primasc) a arcijáhna ,ad sinodum in oppido Uncow vel ubi tunc posita fucrit". K. Korytkowski, Arcybiskupi. Il., s. 119; PEK, 37-38, s. 321; W. Kłapkowski, Dzialalność, s. 68. J. S a w i ck i, $C P$ V., s. 48 se domnivá, žc se mohlo jednat jak o provinciální, tak o diccézni synodu. Účast zástupců poznaňské kapituly na hnčzdenských diccézních synodách dle nčj nebyla neobvyklá.

${ }^{103}$ Zástupci na synodč byly vybaveni čtyřmi hřivnami dict. $A C I E \mathrm{I}$., č. 92, 97, 100, 101, s. 19-21. W. Kłapkowski, Dzialalnośc, s. 68-71.

${ }^{104}$ ACIE I., c. 169, s. 35, č. 1644, s. 350; Dlugoš XIII., s. 559. Józef K. Mçtlewi icz, Synod lęczycki z roku 1435, PMR, 29, 1855, s. 489-507; K. J. He fele, Konziliengeschichte, VIII., s. 11; J. Korytk ow ski, Arcybiskupi, II., s. 137, 139; PEK, 37-38, s. 321; W. Klapkowski, Dzialalność, s. 72 se přikláni k Lęczyci jako místu konáni. I. Sub er a, o. c., s. 92-93.

${ }^{105}$ Dubnová synoda trvala patrnč jcštč 27 . dubna. Řijnová synoda, pokud se konala, mohla být dokončcním synody dubnovć. Na řjjnovou synodu krakovská kapitula delegovala scholastika. $A C I E$ I., č. 1691, 1695, 1696, 1697, s. 368-370; II., č 1086, s. 513; ACCP, c. 6, s. 3. J. Kory tkows k i, Arcybiskupi, II., s. 164-165, 169; PEK, 37-38, s. 321; S. Hain, Wincenty Kot, prymas polski (1436-1448), Pracc Komisji tcologiczncj, III., 2, Poznań 1948, s. 150-151; I. S ubcra, o. c., s. 93. 
krakovské kapituly byli pověřeni vyslovit se na synodě ve prospěch basilejského koncilu ${ }^{106}$. Poslední z řady prokázaných Kotových provinciálních synod se konala 23. dubna 1442 v Piotrkowě ${ }^{107}$.

\section{II.D. Provinciální synody druhé poloviny 15. století}

Celkem pravidelně svolával provinciální synody též Jan VI. Sprowski (1453 - 1464). Dlugoš informuje o provinciální synodě v Lęczyci z r. 1455, „ubi tunc pro ferendo regi charitativo subsidio ... habita est" ${ }^{\text {"108 }}$. Na neznámém místě se konala synoda po 3. listopadu r. $1457^{109}$. V Lęczyci se další konala o dva roky později, dne 17. června 1459 . Na synodě byla vydána statuta;

\footnotetext{
${ }^{106} A C I E$ I., c. $1702,1707,1708,1711$, s. 374-375; $A C C P$, č. 7, 8, s. 3-4; č. 324, s. 86. S. Ha in, Wincenty Kot, s. 151-152; I. Subera, o. c., s. 93-96. Oba mylně datují synodu do 7 . května: svátek sv. Stanislava, na který byla synoda svolána, se tchdy slavil 8 . května; až Kliment VIII. (1592-1605) jej přcsunul na 7. května - Gustav Friedric h, Rukovět kŕestanské chronologie, Praha 1934, s. 331; Chronologia polska, rcd. B. Włodarsk i, Warszawa 1957, s. 257; srov. ACCP. č. 324, s. 86; J. Ko ry tkow ski, Arcybiskupi, II., s. 180-181. Zástupci hnčzdenské kapituly byli probošt, dð̌kan (popř. kanclér), scholastik a kustod. Krakovská kapitula vyslala probošta, scholastika a jcšť jednoho kanovnika. Tentokrát máme informaci i o účasti biskupủ, konkrétně biskupa krakovskćho, włocławskćho, poznaňského, plockćho, a prokurátorů lubušskćho a vratislavskćho biskupa. Podobnč jako vratislavský biskup i vratislavská kapitula vyslala jen jednoho zástupce; $\mathrm{k} 13$. kvčtnu je prokázána prítomnost vratislavskćho kapitulniho dčkana a dále děkana kolegiátní kapituly z Brzcgu v Lęczyci. Přttomni byli též delcgáti basilejského koncilu. CDS XV., č. 96-99, s. 111-114; CP X., s. 417. M. Wi szniews ki, Historya, V., s. 59-60, pozn. 89 uvádí údaje o kázáních z krakovského rukopisu (a citace z nich), která údajně měl Matyáš z Krakova pronćst na łçczycké synodð̌ na oktávu sv. Stanislava (15. kvčtna) a tamtéž 27. dubna. K.J. Hefcl c, Konziliengeschichte, VIII., s. 11 pišc o synodč v Lęczyci konané od 27. 4. do 10. 5. 1441. ${ }^{107} C D S$ XV., č. 99 , s. 114; ACIE 1., č. 1155, s. 233; č. 1714, 1717, 1718, s. 376-377. Włocławská kapitula se účastnila prostřconictvím dvoučlenné delegace (arcijáhen a kanovník), hnězdenská kapitula vyslala probošta a scholastika. J. Korytk owski, Arcybiskupi, II., s. 185-186; PEK, 37-38, s. 321; S. Hai n, Wincenty Kot, s. 158-159; I. Subera, o. c., s. 96. M. Wis zniewski, Historya, V., s. 60 , pozn. 89 informuje o kázání, které údajnč mělo být na synodě proneseno Matyášcm z Krakova a jehož text se nacházi se v rukopise v Krakově.

${ }^{108}$ Dlugoš XIV., s. 198. A. Ohanow ic z, Cięźary państwowe duchowieństwa w Polsce, Studya nad historią prawa polskicgo, III., 3, Lwów 1911, s. 46.

${ }_{109} A C I E$ I., č. 1872, 1876, s. 427-428. Hnčzdenská kapitula určila za své vyslance pro synodu děkana, kustoda, jednoho kanovnika a probošta, ktcrćho posléze nahradil další kanovnik. Obdrželi dictu ve výši šcsti hřiven. J. Kory tk ow sk i, Arcybiskupi, II., s. 284. CP I., s. 22-23; V., s. 65. S. Damalewicz pr̆i zmínce o druhé synodě Sprowského informuje (bez pramenných odkazù) o Kališi jako místu konání a o schválení kontribuce: Ste phanus Damalewicz, Series archiepiscoporum Gnesnensium, atque res gestae, e vetustis antiquitatum ruderibus collectae, Varsaviae 1649, p. 254.
} 
stanovují postup kapituly v prípadě smrti biskupa ${ }^{110}$. Roku 1462 se konala provinciální synoda 5 . záríi $\vee$ Kališi ${ }^{111}$. Kališská synoda prokazatelně schvalovala kontribuci $z$ kléru ve prospěch krále ${ }^{112}$. Před 15. dubnem 1463 byla slavena synoda $v$ Lęczyci ${ }^{113}$. 11 . března 1464 měla v Lęczyci být synoda, není ovšem známo, zda se konala ${ }^{144}$. V dubnu Sprowski umírá a jeho nástupce Jan VII. Gruszczyński (1464 - 1474) ještě téhož roku mezi 5. řjinem a 17. prosincem měl slavit provinciální synodu ve Wolborzu ${ }^{115}$. O lęczycké synodě z 20. ledna 1466 jsme celkem dobře informováni díky Janu Dlugošovi. Za účasti włocławského biskupa Jakuba Szemice, poznaňského Ondřeje Opalińského a třech zástupců krakovského biskupa Jana se jednalo tři dny o

\footnotetext{
${ }^{110}$ Pủvodně se mčla konat 23. dubna. Poznaňská kapitula pro první termin určila kustoda a kanovnika, u druhćho přibyl arcijáhen; všichni zabezpcčcni pčti hřivnami. Hnčzdenská kapitula vyslala probošta a pđ̌t kanovnikủ, včctnč gencrálního vikářc diecéze a oficiála. $A C I E$ I., č. 510, 513,514, s. 98; č 1899, s. 433. Ustanoveni viz ACIE I., č. 516, s. 99 - 101. Constitutiones synodorum Metropolitanae Ecclesiae Gnesnensis Provincialium Authoritate Synodi Provincialis Gembicianae Per Deputatos recognitae Jussu vero et opera Illustrissini et Reverendissimi Domini D. Joannis Węzyk, Dei et Apostolicae Sedis Gratia Archiepiscopi Gnesnensis L. N. R. P. P. editae, Cracoviae 1761, p. 36-38. Constitutiones Synodorum Metropolitanae Ecclesiae Gnesnensis Provincialium Stanislai Karnkowski, Cracoviae 1579, f. 63a. K. J. He fe le, Konziliengeschichte, VIII,, s. 151; J. Koryl kow ski, Arcybiskupi, II., s. 295; PEK, 37-38, s. 321; P. K alwa, o. c., s. 20. Jiné (nedatované) ustanovení Sprowskčho upravující postup při sedisvakanci se dostalo za prostřednictví arcibiskupa Olcśnickćho do souboru synodálnich ustanoveni arcibiskupa Jana Wężyka z r. 1630 a další úsck statut, potvrzený na synodě r. 1485 , sc dostal do souboru arcibiskupa Stanisłava Karnkowskćho z r. 1579 - viz nížc. Damalewicz piše u synody z roku 1459 o schvalování kontribuce. Chybí ovšem odkazy na prameny: Series archiepiscoporum Gnesnensium. atque res gestae e vetustis antiquitatum ruderibus collectae ... per Stephanum Damalevicium vartam, Varsaviae 1649, p. 254-255. Podle Sawického se této synody (datuje ji 17. - 20.6. 1459) týká zmínka v konvokačním listě na hnčzdenskou diecézni synodu patrně z r. 1459; $C P$ V., s. 66-68.

III V aktech poznañské kapituly je u únorových zápisů řcč o termínu 14. března; kapitula určila jako zástupce dčkana, kustoda a dva kanovniky, a každćho vybavila na cestu třcmi hřivnami. $A C I E$ I., č. 553, s. 107. Podle záznamu v aktech hnězdenské kapituly z poloviny ledna měl arcibiskup synodu svolat na 24 . čcrvna. Záznamy kapitulních akt vymezuji datum konáni na období mczi 30. srpncm a 24. září - viz ACIE I., č. 1925, s. 440. ACIE I., c. 558-562, s. 108; ACCP, č. 80, s. 21. Dlugoš. XIV., s. 357 informujc o datu 5. záŕi. J. Kory tkow s ki, Arcybiskupi, II., s. 309, 314; PEK, 37-38, s. 321; CP I., s. 23.

${ }^{112}$ Dlugoš, XIV., s. 357. A. Ohanowicz, Ciężary, s. 44, 73-74.

${ }^{113.3} A C I E$ I., č. 564, s. 109.

114 Poznaňská kapitula určila za své zástupce kustoda a arcijáhna, krakovská dva kanovníky. $A C I E$ I., č. 570, s. 109; ACCP, č. 119, s. 26. J. Korytk ow ski, Arcybiskupi, II., s. 323 datuje mylně 19. břczna. A. Ohanowicz, Ciężary, s. 44, 74; CP I., 23.

${ }^{115}$ Krakovská kapitula vyslala opčt dva kanovníky, ktcré vybavila osmi hřivnami dict. Zástupci poznaňskć kapituly, arcijáhen a kanovník, dodatcčnč obdržcli po deviti hřivnách dict. $A C I E$ I., č. $582,586,588$, s. $112 ; A C C P$, č. 128 , s. 29 . J. Koryt kows ki, Arcybiskupi, II., s. 349. A. O hanow ic z, Cięźary, s. 74.
} 
kontribuci v církvi pro krále Kazimíra. Byl vynesen rozsudek nad hnězdenským arcijáhnem pro vraždu ${ }^{116} . Z$ podnětu krále Kazimíra svolal arcibiskup rovněž synodu na 12. března 1469 do Lęczyce, jak vyplývá $z$ jeho konvokačního listu $z 18$. ledna adresovaného krakovskému biskupovi ${ }^{117}$. Počátkem srpna r. 1469 Gruszczyński požádal hnězdenskou kapitulu, aby stanovila termin a místo konáni príští synody ${ }^{118}$. Nicméně prríští provinciální synoda se slavila až 14. dubna 1472, opět v Lęczyci. Primas pohrozil hnězdenské kapitule exkomunikací, jestliže na synodu nevyšle své zástupce ${ }^{19}$. Požadavky na kontribuce pro krále vyvolaly takovou vlnu nevole, že když arcibiskup počátkem prosince 1472 stanovil termín nové lęczycké provinciální synody (na 3. leden 1473), hnězdenská kapitula okamžitě iniciovala několik porad. Zaslali listy włocławské a poznaňské kapitule a vyslali posly ke králi Kazimírovi a $\mathrm{k}$ arcibiskupovi ${ }^{120}$.

K roku 1474, po smrti Gruszczyńského, jsou zápisky akt hnězdenské kapituly zmatečné. Administrátor hnězdenského arcibiskupství Uriel Górka svolal synodu na 2 . února do Lęczyce. Zmíněná akta hnězdenské kapituly opět odhalují krále coby iniciátora a kontribuci jako předmět, který měl být projednáván. Pokračovat měl v Hnězdně. Dne 13. března, ještě před zahájením synody došel metropolitni kapitule v Hnězdně list, ve kterém Jakub ze Sienny, nový arcibiskup, žádá odložení synody ${ }^{121}$. Na 22. ledna 1475 svolal arcibiskup synodu kvůli novému schválení kontribuce.

${ }^{116}$ Dlugoš XIV., s. 426 - 427. Poznan̆ská kapitula vyslala kustoda a śremskćho arcijảhna a vybavila je pěti hřivnami diet. Hnězdenská kapitula se nechala zastupovat šcsti svými člcny, mimo jinć dčkancm a gencrálním vikářcm - oficiálem. Dostali po pčti hřivnách. $A C I E$ I., č. 597, s. 114; c. 1978, s. 454. K.J. Hc fcl c, Konziliengeschichte, VIII., s. 190; J. Korytkows ki, Arcybiskupi, II., s. 357-358; PEK, 37-38, s. 321; A. O hanowicz, Cięźary, s. 74.

117 J. Kory tk ow s ki, Arcybiskupi, II., s. 368-370, pozn. 2; ACIE II., s. 260-262. PEK, 37-38, s. 321; $C P$ V., s. 71-72. Hnčzdenská kapitula vyslala probošta, kantora, kustoda a tři kanovníky, poznaňská kapitula probošta, dčkana, kustoda a jednoho kanovníka; obč kapituly určily každému po šcsti hřivnách dict. $A C I E$ I., č. 607, s. 116; č. 2015, s. 463-464.

${ }^{118} A C I E$ I., č. 2026, s. 465 . Srov. $C P$ V., s. 72.

${ }^{119}$ Hnězdenská kapitula nakonec vyslala tři zástupce: kustoda a dva kanovníky (Šest hřiven dicty). Poznaňskả kapitula mčla jako zástupec kustoda a kanovnika (pčt hřiven dict obdržcli). ACIE I., č. 619, s. $118-119 ;$ č. 2051, s. 471. A. Ohanowicz, Ciężary, s. 75. J. Kory tkowsk i, Arcybiskupi, II., s. 377-378; J. Koryt kow ski, Pralaci, I., s. 369; CP I., s. 18. Korytkowski (Arcybiskupi, II., s. 374-375) jcštč mylnč prohlásil diccézní synodu z r. 1471 v Lęczyci za provinciální; opravil J. Sawicki, $C P$ V., s. 73.

${ }^{120}$ ACIE I., c. 624, s. 119-120; દ. 2067-2071, s. 474-475. J. Korytk ow ski, Arcybiskupi, II., s. 380-381; J. Korytkowski, Pralaci, I., s. 372; PEK, 37-38, s. 321.

${ }^{121} A C I E$ l., č. 2101-2106, s. 482-483. Tři kanovníci, ktcrí v Lęczyci měli zastupovat hnězdenskou kapitulu, si 21 . břczna vyžádali šcst hřiven za výdajc. Kdy se synoda doopravdy konala, není možnć určit. J. Korytkowski, Arcybiskupi, II., s. 418 - 419; Týž, Pralaci, I., s. 385; $P E K, 37-38$, s. 321. Nelze řici, jestli se pak synoda po sejmu konala. 
Hnězdenská kapitula nesla s nelibostí, že tak učinil bez jejího souhlasu; vyslala zástupce, který měl vyjádřit její nesouhlas $\mathrm{s}$ vybíráním daní ${ }^{122}$. Rovněž před lęczyckou synodou z r. 1476 se hnězdenská kapitula radila o svém postupu, a to i s třemešským opatem, děkanem $z$ Włocławku a se zástupcem kapituly poznaňské ${ }^{123}$. Poslední z Jakubových provinciálních synod byla svolána na 27 . února $1480^{124}$. Místem, na kterém se všechny provinciální synody Jakuba ze Sienny měly sejít, byla opět Lęczyca.

Bohatší pramennou základnu nalezneme při pátrání po provinciální synodě Zbigniewa Oleśnického $(1480$ - 1493) z roku 1485. S určitostí víme, že synodní shromáždění v Piotrkowě zasedalo ve dnech ve dnech 21. - 22. ledna. Na svatou Anežku (21. leden) pohání notár̆ Ondřej z Wieluně do Piotrkowa na provinciální synodu lęczyckého kanovníka Ondřeje z Kraszyc ${ }^{125}$. Dne 22. ledna na ní byla vydána statuta, která se nám dochovala v souboru ustanovení Jana Wężyka $z$ roku 1630. Primas Oleśnicki v rich inovuje starši ustanovení svého předchůdce Jana Sprowského, které upravuje postup při sedisvakanci ${ }^{126}$. Podle Janockého byl údajně autorem statut vydaných na piotrkowské synodě Mikuláš Kotwicz ${ }^{127}$. Ze synody mělo podle J. Korytkowského a starších autorů pocházet rovněž „Doctoris Nikolai Kottwicii decisio de interdicto et excomunicatione"; jiné Kotwiczovo ustanovení „de raptoribus" se dochovalo ve statutech

${ }_{122}$ ACIE I., č. 2125, 2126, s. 489. J. Kory tkows ki, Arcybiskupi, II., s. 422-423; A. Ohanowic z, Ciężary, s. 42, 75; $C P$ V., s. 81 .

${ }^{123}$ Konala sc po 21 . řjjnu, kdy jednáni probihalo. Poznañská kapitula vyslala scholastika a jednoho dalšiho kanovnika. Hnčzdenská kapitula vyslala dva kanovniky. ACIE I., ¿. 658, 659, s. 124 ; č. 2139,2140 , s. 492 . J. Korytkowski, Arcybiskupi, II., s. $430-431 ;$ PEK, 37-38, s. 321 ; CP V., s. 83.

${ }^{134}$ Hnčzdenská kapitula určila své zástupce, dva kanovníky a přrirkla jim obvyklých šcst hřven dict. Zástupci krakovskć kapituly (dčkan a kanovnik) mčli na synodč vyjádřit svć odmitavé stanovisko vưči kontribuci. $A C I E$ I., č. 2207, s. 508. ACCP, č. 232, 236, s. 59-61. J. Kory tk ow s ki, Arcybiskupi, II., s. 440; PEK, 37-38, s. 321; A. Ohan ow icz, Ciężary, s. 75; CP I., s. 21.

125 J. Korytk owski, Arcybiskupi, ll., s. 465, pozn. 3. Poznañská kapitula 13. ledna určila svého zástupce na synodu (obdržel deset hřiven na diety), a již 7 . ledna tak učinila włocławská kapitula; své dva zástupcc vybavila dvanácti hřivnami-ACIE I., č. 735-737, s. 138-139; č. 1280, s. 267. K 4. dubnu je v aktcch poznaňskć kapituly záhadná zmínka o provinciální synodč stanovené na 17. dubna - ACIE I., č. 747, s. 140. Srov. P. Kałwa, o. c., s. 20; PEK, 37-38, s. 321; I. Subera, o. c., s. 97.

${ }_{126}$ Constitutiones... Joannis Węzyk, p. 33-45. Constitutiones Synodorum...Stanislai Karnkowski, Cracoviac 1579, f. 61b-66b. Statuta podávaji jmenovitý výčct rady významných účastnikủ, který mimo jinć potvrzuje účast zástupcủ delegovaných poznañskou a włoclawskou kapitulou. $Z$ biskupủ se účastnili toliko wloclawský Petr a plocký Petr. Srov. M. W is zn i c ws ki, Historya, V., s. 81.

${ }_{127} \mathrm{Jan}$ Daniel Andrzej J a ocki, lanociana sive clarorum atque illustrium Poloniae auctorum maecenatumque memoriae miscellae, t. II., Varsaviae et Lipsiae 1779, p. 133; t. III., ed. S a mu el Theophilus LINDE, Varsaviae 1819, s. 231. Srov. J. Korytkowski, Pralaci, II., s. 315. 
Laského z r. $1528^{128}$. Piotrkowská synoda trvala tři dny, jak dosvědčuje text statut na synodě vydaných ${ }^{129}$. O rok později (1486) byla synoda svolána do Kłodawy na 5 . března ${ }^{130}$. Záznamy $\mathrm{v}$ aktech hnězdenské kapituly $\mathrm{z}$ konce července 1487 informují o provinciální synodě, která se téhož roku měla konat 17 . srpna $\mathrm{v}$ Lęczyci. Włocławská kapitula ovšem své zástupce na synod jmenovala až 16 . srpna; vyvstává otázka, zda výše uvedené datum bylo termínem konečným ${ }^{131}$. Ve dnech 14. 15. ř́jna 1489 slavil Oleśnicki v Lęczyci svoji poslední provinciální synodu. Byl projednávána opět nová kontribuce, dále např. spor o přednostní místo na provinciální synodě mezi plockým a poznaňským biskupem; klášteru řeholních kanovník̊̊ v Kłodawě arcibiskup udělil právo výlovu ze dvou rybnikü ${ }^{132}$.

Svoji patrně první provinciální synodu hnězdenský arcibiskup Fryderyk kardinál Jagiellończyk (1493 - 1503) slavil 13. července 1496. Na synodě byla schválena kontribuce ve výši jednoho verduňku $\mathrm{z}$ hřivny stříbra; bylo rozhodnuto o termínu př́ítí provinciální synody (21. ledna následujícího roku) ${ }^{133} .13$. července 1497 se patrně konala provinciální

\footnotetext{
${ }^{128}$ M. Wis zn i ews ki, Historya, V., s. 73; A. Joche r, Obraz bibliograficzno-historyczny literatury inauk w Polsce, III., Wilno 1857, s. 373, č. 7490; J. Korytk ow s ki, Pralaci, II., s. 315. Nepodařilo se mi prokázat, žc by ustanoveni obsažcné v právni sbirce Laského (1506) a v provinciálnich statutcch z r. 1528 pocházclo ze synody r. 1485: J. Lask i, Commune incliti Poloniae Regni privilegium constitutionum et indultum publicis decretorum approbatorumque, Kraków 1506, f. 69b-74a; Statuta provincie Gnesnensis. Antiqua et nova, revisa diligenter et emendata, Cracoviae 1528, V., kapitola 5 „De raptoribus. In sinodi Petrcoviensi quarta“ (nepaginováno). i29 Constitutiones ... Stanislai Karnkowski, f. 62b.

${ }^{130}$ Krakovská kapitula vyslala dva kanovniky; krakovskćho biskupa zastupoval děkan kapituly, J. Korytk ow ski, Arcybiskupi, II., s. $469-470$, pozn. 4; ACCP. č. 258, s. 68. Korytkovski se domnivả, žc se synoda ve stanovenćm termínu nckonala.

${ }^{131}$ Hnčzdenská, wlocławská a poznaňská kapitula vyslaly po dvou kanovnících ( $z$ toho włocławská kapitula jednoho scholastika) - ACIE I., c. 782, s. 146; č. 1288, s. 269; č. 2275, s. 523. Srov. J. Kory tkowsk i, Arcybiskupi, II., s. 473; PEK, 37-38, s. 321.

132 Poznaňská kapitula vyslala dva kanovníky, włocławská kapitula probošta, dčkana, scholastika a jednoho dalšího kanovníka a hnězdenská kapitula dčkana a jednoho kanovnika. ACIE I., č. 793 , s. 147; č. 1298 , s. 271 , c. 2295-2303, s. 526-527; 1l., c. 686, s. 321-322; J. Kory tkowsk i, Arcybiskupi, II., s. 478-479, pozn. 10; PEK, 37-38, s. 321. S. Da malew icz, Series, p. 269 ještč informuje o synodd z r. 1481, chybí ovšcm pramennć dủkazy.

${ }^{133}$ Hnčzdenskou kapitulu zastupovali dva kanovníci, poznaòská kapitula delegovala arcijáhna a scholastika, włoclawská kapitula svćho děkana. ACIE I., c. 2468, 2469, 2472, 2473, s. 555556 ; c. 1333 , 1334, s. 279; č. 859-863, s. 158-159; ACCP, c. 509, s. 123. Srov. J. Kory tkow ski, Fryderyk Jagielloniczyk. Kardynal, arcybiskup gnieżnienski i biskup krakowski, odbitka z Przcglądu kościclnego, Poznań 1881, s. 25; J. Korytkow sk i, Arcybiskupi, II., s. 508; PEK, 37-38, s. 321; H. R y bu s, Kardynal Fryderyk Jagiellonczyk jako biskup krakowski i arcybiskup gnieźnienski, Studia historico-ecclesiastica, n. 2, Warszawa 1935, s. 137-138; CP V., s. 89.
} 
synoda v Kłodawě. Byla zde odsouhlasena další kontribuce ${ }^{134}$. V polovině následujícího roku ohlásil arcibiskup další synodu. Nejbližší známou provinciální synodou je až lęczycké shromáždění z 17. února $1499^{135}$. Roku 1501 byla provinciální synoda svolána na 22. dubna do Koła. Nejspíše se ale konala na přelomu dubna a května, jak vyvozuje $H$. Rybus (ve dnech 29. dubna až 1 . května byla vydána v Lęczyci králem Janem Olbrachtem privilegia pro některé církevní instituce). Předmětem jednání měla být contribucio dupla, schválené na sejmu v Piotrkowě ${ }^{136}$. Ǩadu synod slavených $\mathrm{v}$ době episkopátu Fryderyka uzavírá lęczycká provinciální synoda $z 21$. ledna 1503 . Vedl ji lvovský arcibiskup Ondřej Boryszewski. Opět schválila kontribuci ${ }^{137}$. Byla na ní vydána statuta; byla před synodou již 10 . ledna připravena. Obsahuje 48 kratších článků dotýkajících se rozličných oblastí správy provincie, práva, výkonu bohoslužeb. Zajímavá je zminka o scholárech z Cech: nemají hýt ponecháváni ve školách, aby neovlivňovali ostatní1 ${ }^{138}$.

\footnotetext{
${ }^{134} \mathrm{O}$ tomto tcrmínu a mistu synody nás informuji akta plocké kapituly (z 15. čcrvna). Poznaňská kapitula jednala 13. čcrvna o provinciálni synodé, ktcrá se má konat 24. cervna v Piotrkowě. Správná jc lokace synody do Klodawy, jak potvrzuji záznamy hnězdenské a włocławské kapituly, které vznikly po synodč. $A C I E$ I., č. 874, s. 160; č. 1339, s. 280; c. 2487, s. 558; č. 2494, s. $560 ; A C C P$, c. 510, s. 123. J. Kory tkow ski, Fryderyk Jagiellończyk, s. 28-29; Týž, Arcybiskupi, Il., s. 510-511; PEK, 37-38, s. 321; A. Oh a now ic z, Ciężary, s. 77 (všichni tři autoři píš́ o piotrkowské synodě). H. R y bus, Kardynal Fryderyk, s. 138-139 (uvádí věc na pravou míru); $C P$ V., s. 90. lanociana, II., p. 96-97 informuje o statutcch vydaných na provinciální synodě v Piotrkowě v sobotu před sv. Jiljim, tj. 26. srpna (odkazuje se na hrabětc Zaluského, který je měl zarcgistrovat $\mathrm{v}$ rukopise $\mathrm{v}$ Krakove) $)$.

${ }^{135}$ ACIE I., č. 898,899 , s. 166; č. 1341, 1342, s. 281 ; ‘. 2509 , s. 562. Termin byl určen na neděli Invocavit, která r. 1499 připadá na 17. února, nikoliv na 18. února, jak uvádi J. Ko ry tkow sk i, Fryderyk Jagielloniczyk, s. 35; Týž, Arcybiskupi, II., s. 515; PEK, 37-38, s. 321 a H. R y bus, Kardynal Fryderyk, s. 140-141. CP V., s. 91.

1.56 ACIE I., ๕. 921, s. 173; ґ. 2566, 2568, s. 571-572. ACIE II., č. 1558, s. 701. H. Rybus, Kardynal Fryderyk, s. 142-144; CP V., s. 91. J. Ko ry t k ow s ki, Fryderyk Jagielloniczyk, s. 4142; Týž, Arcybiskupi, II., s. 519; Týž, Pralaci, I., s. 388; PEK, 37-38, s. 321; A. Oh a nowic z, Ciężary, s. 77; CP V., s. 91.

${ }^{137}$ Poznañská kapitula vyslala na synod arcijảhna (gencrálního oficiála) a jednoho kanovníka (dostali po šcsti hřivnách dict), włocławská kapitula povčrila zastupovánim kantora a jednoho kanovnika a hnčzdenská kapitula arcijáhna a kanovnika (pčt hřiven dict). $A C I E \mathrm{I}$., č. 946, 947, s. $178-179$; c. 1360 , s. 286; č. 2582-2584, s. 576; č 2604, s. 579. Srov. PEK, 37-38, s. 321; A. Ohanowicz, Ciężary, s. 77; $C P$ V., s. 93.

${ }^{138}$ ACIE I., č. 2585, s. 576. J. Koryt kowski, Fryderyk Jagielloniczyk, s. 46; H. Ry bus, Kardynal Fryderyk, s. 145-149, 215-227 (edice).
} 


\section{Charakteristiky provinciálního synodálního života Hnězdna. Shrnutí, závěr}

Periodizace. V rámci celku provinciálních synod hnězdenské církevní provincie ve středověku lze vysledovat několik období. První období, které se časově kryje s 13. stoletím a zasahuje do počátku století následujicího, je dobou emancipace polské církve. Synody se často musely zabývat konflikty mezi světskou mocí a mocí církevni. 13. století je také dobou masivního prosazováni církevního práva do života církve a kanonickoprávních pravidel do každodeního života kléru a farníků. Prostřednikem prri prosazování těchto cílů se staly legátské synody. Dobou rozkvětu pro ně byla druhá polovina 13 . století. Zato 14 . století je od své druhé čtvrtiny obdobím klidu synodálního i legislativního; výjimkou je synodyk Jarosława Skotnického. V 15. století hnězdenští arcibiskupové provinciální synody svolávali často a hlavně pravidelně. Polská církev a její právní život byl obohacen o Trąbovu kodifikaci. Ve vztahu církve a státu zaujímaly provinciální synody $\mathrm{v}$ druhé polovině 15 . století $\mathrm{s}$ presahem do století následujícího pasivni roli - stávají se schvalovacím orgánem kontribucí z kléru pro potřebu krále.

Nařizeni o konáni provinciálnich synod; impulsy $k$ jejich svolávání. Frekvence konání. V celém západokřest'anském světě bylo hlavním impulsem pro zahájení svolávání juristicky vyhraněných provinciálních synod vrcholného středověku usnesení 4. lateránského koncilu, které se později stalo součástí Liber extra. Další podněty ke svolávání provinciálních synod ve hnězdenské provincii vyrůstaly $\mathrm{z}$ podhoubí konkrétních situací. Legát Guido ve svých statutech z počátku r. 1267 předpokládal, že arcibiskup svolá provinciální synodu, na které budou publikována jeho statuta. $Z$ téhož roku (1267) je známa synoda arcibiskupa Janusze z Dankowa. Inocenc VII. vyzval arcibiskupa Mikuláše Kurowského k odbytí provinciálni synody, která by zaujala jasné stanovisko v situaci schizmatu. Následně svolal Kurowski synodu do Kališe (1406), kde rozhodl o pravidelném svolávání provinciálních synod arcibiskupem či jeho zástupcem ve tříletých intervalech. Inicioval rovněž ročni svolávání diecézních synod. Nařízení bylo dokonce sankcionováno: arcibiskup, který by je nedodržel, zaplatí pokutu sto hřiven pražských grošů metropolitní kapitule. Ustanovení o konání provinciálních synod v trríletém intervalu opakuje Mikuláš Trąba ve statutech r. 1420. Roku 1422 ke konáni provinciální synody vyzval Mikuláše Trąbu opět papež (tentokrát Martin V.). Papež nepřimo inicioval i další provinciální synodu (z r. 1425), když hnězdenskému arcibiskupovi připomněl jeho vizitační 
povinnost. Podněty ke svolávání v druhé polovině 15 . století vycházely ve valné většině př́ipadů od krále, který potřeboval schválit kontribuce predtím většinou dohodnuté na valných sejmech.

Termíny a délka konání. Předpokládáme, že ve se synody konaly více než pouhý jeden den. Potom ale $v$ mnoha připadech známe toliko datum prvního dne konání synody, dne, na nějž byla synoda svolána; jindy zase den, kdy byla vydána statuta. Na synodě r. 1287 byl vydán na třetím sezení ("tercia accione") dne 26. řjina notářský instrument. Tři dny se prokazatelně konaly provinciální synody r. 1262, 1357 a 1406. U synody z r. 1466 nám dosvědčuje Dlugoš, že se konala tři dny. Statuta z r. 1485 prímo zmiňují trí́denní trvání provinciální synody. Délka dvou dnů byla prokázána u provinciální synody $\mathrm{z} \mathrm{r}$. 1489. Čtyři dny určitě byla slavena synoda $\mathrm{z} \mathrm{r}$. 1233 v Sieradzu. Pět dnů asi trvala dubnová synoda z r. 1440. Některé synody své jednání přerušily a dokončily $\mathrm{v}$ jiném termínu, př́padně i na jiném místě. Takto to bylo $\mathrm{v}$ prípadě wieluńské synody Mikuláše Trąby svolané na 13. leden. Byla odročena na 15 . záŕí do Kališe, kde také byla 25. zárí vyhlášena kodifikace. Je možné, že i dubnová synoda z r. 1440 byla dokončena na podzim. Hromadné opakování denních dat, na něž byly synody svolávány, nelze až na výjimky vysledovat. Často se objevují jako data svolání pohyblivé svátky. Galerii světců, na jejichž svátky se provinciální synody konaly ( $\mathrm{v}$ mnohých prípadech vícekrát), vyplňují sv. Anežka (12. březen), sv. Tiburcius a Valerián (14. duben), sv. Vojtěch (23. duben), sv. Stanislav (8. květen), sv. Markéta (13. července), sv. Bartoloměj (24. srpen), sv. Vavřinec (10. srpen), sv. Lambert (17. záŕí), sv. Kalixt (tj. den před sv. Hedvikou, 14. ř́jen), sv. Hedvika (15. ř́ijen). Jedna synoda byla svolána na svátek Očištování Panny Marie (2. únor). Jak vyplývá z kapitulních akt 15 . století, termín synody určoval arcibiskup. Roku 1469 vyzval primas Jan Gruszczynski hnězdenskou kapitulu, aby rozhodla o termínu a místě konání provinciální synody. Členům kapituly, kteři by se jednání o synodě nezúčastnili, měl hrozit půhon.

Mista konání. V 13. století se provinciální synody konaly $\mathrm{v}$ neidentifikovaném Borzykowě (či Borzykowé, 1210), ve Wolborzu (před 1215 včetně), možná též ve Witowě a opět neidentifikovaném „Chelou“, dále $\mathrm{v}$ asi Kamieńi (kolem 1217). Z roku 1226 neznáme místo konání synody, zato víme, že se konal v kostele sv. Blažeje. v Lęczyci byla slavena synoda r. $1257,1285,1287$. Synodálním místem se stala též Wroceryż (1258), Sieradz (1262, 1270), Dankow (1267) a Pajęczno (1269). I Hnězdno, sídlo arcibiskupa, se stalo centrem konání synodních jednání a obřadů (1290, před 1309). Zbylé dvě známé synody 14. století (1326, 
1357) byly slaveny v Uniejowě a Kališi. Četné provinciální synody 15 . století se většinou slavily v Lęczyci; dalšími synodálními místy byly Kališ, Uniejow, Wielun, Wolborz, Piotrkow, Kłodawa, Koło a možná Hnězdno.

Úcastnici synod. V 13. století hlavním pramenem informujícím o zúčastněných osobách, jsou listiny; doplňkovým pramenem jsou narativní prameny. Mezi účastníky synod jsou jmenováni hlavně biskupové. Svědečná formule listiny vydané na jedné z prvních provinciálnich synod, borzykowské z r. 1210, atypické díky paralernímu konání knižecího kolokvia, obsahuje kromě jmenovitě uvedených biskupů, několika proboštů, arcijáhna a kustoda obecnou formulaci ,...et alii quam plurimi abbates, prepositi, decani, archidiaconi, canonici, sacerdotes, clerici, et tota sinodus in Boricov celebrata". $U$ synody $z \mathrm{r}$. 1258 máme prokázánu účast členů sedmi polských katedrálních a kolegiátnich kapitul, kromě arcibiskupa a tři biskupů. V 15. stoleti se situace mění; kapitulni akta, která se stávaji nejvýznamnějším pramenem pro zmapování účasti na provinciálních synodách, podávaji jmenovitý výčet zástupců katedrálních kapitul vyslaných na synodu. Často jmenovaným zástupcem hnězdenské kapituly je takto koncem 15. století kanovník, doktor kanonického práva Klemens z Piotrkowa. Kapituly vysílaly své zástupce, povětšinou dignitáře kapituly (probošt, děkan, scholastik, kantor, arcijáhen, kustod) a často současně držitele biskupských úřadů (oficiál, generální vikář), $v$ počtu dvou až čtyř, výjimečně i víc. Informováni jsme i o výši diet, které byly pro delegáty kapitulami schvalovány (rozpětí 1 - 12 hřiven na osobu; nejčastěji šest). Roku 1441 se hnězdenská kapitula usnesla, že ji na synodách budou zastupovat toliko probošt a děkan. Obraz o osazenstvu piotrkowské synody z r. 1485 nám umožňuje si vytvořit svědečná formule provinciálních statut. R. 1279 legát Filip z Fermo ustanovil, že provinciálni synody se musí zúčastnit všichni nositelé duchovních důstojenství, jak světských, tak řeholních, pokud neobdrží zvláštní povoleni od svých nadřizených. Ti, kteři se zúčasnit nemohou, se nechají omluvit klerikem, který je rovněž seznámí se synodními snešeními. Při cestě na synodu a zpět se mají chovat ctnostně, při pohoštěni, které by mělo být též odpovidajíci, maji vystupovat rozvážně a umírněně. Podrobně je rozepsáno, $v$ jakém oděvu maji být na synodě: „....archiepiscopi, episcopi, abbates, et quilibet alii, qui ex privilegio mitris utuntur, mitrati cum superpelliciis, stolis, et cappis, seu pluvialibus, prepositi vero, priores, et alii inferiores prelati cum superpelliciis et stolis, si diaconi saltem sint, et, si velint, pluvialibus 
seu cappis, rectores vero et simplices sacerdotes cum cottis seu superpelliciis et stolis tantum, inferioris vero status vel ordinis clerici, cum cottis synodum intrent, et in ea devote et cum reverentia usque ad finem, nisi casus necessitatis emerserit, perseverent.“ Nejvyšší hodnostáři, konkrétně biskupové, měli podle skutečného či pomyslného významu jejich biskupství své pevné místo při synodních obřadech. Mnohdy vznikaly konflikty o první postavení po arcibiskupovi, jako tomu bylo na synodě r. 1226 (spor mezi krakovským biskupem Ivem a vratislavským Vavřincem). Rovněž roku 1489 byl na provinciální synodě řešen vleklý spor mezi plockým a poznaňským biskupem o přednostní místo na synodě. Spor o prvenství mezi biskupy z Poznaně a Plocka byl řešen i na synodě r. 1499. R. 1472 musel primas pohrozit hnězdenské kapitule exkomunikací, jestliže na synod nevyšle své zástupce.

Prủběh shromážděni. O průběhu synodních shromáždění jsme velmi kuse informováni. O to více zhodnotíme informace $\mathrm{z}$ úvodu piotrkowských statut Zbignieva z Oleśnice (1485): „....Invocata prius Spiritus sancti gratia, ac missa solenniter de Spiritu sancto per nos celebrata. Insuper cantatis et lectis litaniis, antiphonis, aliisque devotis orationibus cum hymno, Veni creator Spiritus, in talibus ordinatis, Deoque suppliciter et devote exhibitis, ac sermone ad clerum per unum in theologia professorem, et alium in decretis doctorem, in presentia ipsius synodi facto, omnibusque divinis per actis, ad tractatus synodales cum ipsis dominis episcopis, nuntiis, procuratoribus, abbatibus, praelatis et clero processimus, quas triduo in ecclesia parochiali dicti oppidi continuavimus...“. Arcibiskup Jarosław Skotnicki r. 1357 přikázal zachovávat tajemství o synodních poradách. Na synodě r. 1420 účastníci nehráli ani zdaleka pasivní roli, aktivně se účastnili projednávání ustanovení nové kodifikace.

Projednávaná témata. $\mathrm{Z}$ definice provinciální synody vyplývá, že se pod vedením arcibiskupa, popř. jiné pověřené osoby, zabývá činností správní a zákonodárnou. Synody se ovšem neomezovaly pouze na tyto akty. Mnohdy byla projednávána aktuální politická situace, dotýkala-li se života církve polské či obecné. Přikladem může být slezský zápas mezi biskupy a piastovskými knižaty (např. r. 1257, 1287) či papežské schizma a s ním spojená potřeba či nutnost vyslovit se ve prospěch konkrétní strany $(1406,1440,1441)$. Jak již bylo zmíněno, $\mathrm{v}$ druhé polovině 15 . století dominuje na provinciálních synodách schvalování kontribuce. $Z$ nejedné synody máme doklad o 
řešení soudních sporů. Tak wolborzský synod (někdy před 1215) se zabýval sporem mezi kujavským biskupem a klášterem ve Strzelně o desátky, r. 1233 byl na synodě obnoven spor tři benediktinských opatů s premonstráty. V Lęczyci, na provinciální synodě r. 1466, byl souzen hvězdenský arcijáhen pro vraždu. R. 1485 pohání notář na provinciální synodu lęczyckého kanovníka Ondřeje z Kraczyc. Provinciální synoda se stala i místem pro uzavrení smluv - r. 1298 na synodě v Hnězdnu byla stvrzena výměna obcí mezi arcibiskupem a Florianem z Pątnowa. Jakub Świnka na jedné ze svých synod (před 1306) vedl proces proti krakovskému biskupu Muskatovi ${ }^{139}$.

Provinciálni statuta. Prvními doloženými statuty hnězdenského arcibiskupa jsou statuta Henryka Kietlicze. Ač nemáme př́mé důkazy, obecně se předpokládá, že byla vydána někdy kolem r. 1217, a to na provinciální synodě. Dvojí statuta známe od Pełky, $\mathrm{z}$ toho jedny pochází nesporně ze synody z r. 1233 . V nich vzpomíná statuta svých př̀dchůdců. Godysław Pasek ve své kronice připomíná mnohá ustanovení, která měl Pełka vydat na synodě r. 1257. K synodě z r. 1285 jsou řazena nejrozsáhlejší statuta Jakuba Świnky. Jakubu Świnkowi je dále prriřazováno několik nedatovaných zlomků statut. Součástí právního rádu církevní provincie se stala i legátská statuta, která měla vyšší právní sílu než provinciální statuta metropolitů. Provinciální zákonodárství formovala i legátská statuta z r. 1248, 1253, 1267, 1279, 1287, 1302 a 1309. Statuta známe ze synod Janisława z r. 1326 a Jarosława z r. 1357. Do 15. století, přes množství synod chudého na provinciální statuta, vstoupíme se synodními snešeními Mikuláše Kurovského z r. 1406. Zlomky se dochovaly ze statut Jana Sprowského (1459) a Zbigniewa Oleśnického (1485). Ve statutech z r. 1233 je obsažena formulace „(nos Fulco Gnesnensis archiepiscopus)... constitutiones subsciptas de consensu fratrorum nostrorum et aliorum ecclesie prelatorum edidimus...", která, není-li pouhou zdvořilostní frází, vyjadřuje určitou roli sufragánů a dalších prelátů při normotvorbě. Svoji roli sehráli biskupové a preláti i při sestavování Trąbovy kodifikace z r. 1420. Snaha o zpřehlednění právní situace a zesystemizování roztř́štěných ustanovení spousty statut jednotlivých arcibiskupů vedla $\mathrm{k}$ pokusům o vypracování kodifikace. První krok učinil Jarosław Skotnicki

\footnotetext{
${ }^{1.39}$ Srov. P. K ra fl, Přehled provinciálnich synod, s. 8-12. Týž, Akta katedrálních kapitul, s. 37 - 43. Srov. M. Moraws ki, Synod prowincjonalny; AK, 21, 1935, sv. 35, s. 140-163; I. S uber a, Synody, s. $14-35$.
} 
v polovině 14 . století. Jeho synodyk z r. 1357 byl ovšem pouze prostým shrnutím starších provinciálních statut. Štafetu převzal arcibiskup Mikuláš Trąba a úsilí dovedl ke zdárnému konci. Jeho wieluńskokališská statuta $\mathrm{z}$ r. 1420 nejsou již pouhým shrnutím dřive vydaných ustanovení - kodifikace má systematický charakter a kopíruje strukturu knih papežských dekretálů. Byla výlučná140.

Publikace synodnich ustanovení. Legát Guido vyžadoval, aby jeho legátská statuta byla na diecézních a na provinciálních synodách předčítána. Laici měli být seznámeni s ustanoveními, která se jich týkala, ve farních kostelich ${ }^{141}$. Do šesti měsíců od publikace wieluńskokališských statut $\mathrm{z}$ r. 1420 měly být tyto, opatřené Trąbovou pečetí, popr. pečetěmi ordinár̆ů, dostupné ve všech katedrálních a kolegiátních kostelích. Je zakázáno používat starší provinciální statuta ${ }^{142}$. Kronika Godysława Paska nám k polovině 13. století dosvědčuje, že uložení statut u katedrálních kostelů bylo samozřejmostí1 ${ }^{143}$. Lze předpokládat, že při katedrální kapitule byla vedena úřední kniha s opisy provinciálních statut. Doklad o existenci takovéto knihy, „liber statutorum“, nám k roku 1381 přináší notářský instrument, do něhož bylo několik ustanovení starších statut transsumováno ${ }^{144}$. Další doklad o úřední knize je $\mathrm{z}$ r. 1415, kdy notář a současně písař akt hvězdenské kapituly připravil notářský instrument, který transsumoval statut Jakuba Świnky De anno gratie ${ }^{145}$.

Závěr. Přehled probrané tématiky provinciálních synod hnězdenské církevní provincie ukazuje, že synodální aktivity, synodální ,život"a normotvorba byly velmi pestré, různorodé a bohaté; procházely velmi bouřlivým vývojem. Každé ze století polského středověku od 4 . lateránského koncilu vykazuje svoje specifika; synody reagují na potřeby své doby. Ve značné míre míra synodálních aktivit odvisí od osobnosti arcibiskupa, jak se ukazuje zvláště v 13. a 14. století. Ošemetnou se též ukazuje schématická aplikace rigorózních definic provinciálních synod na konkrétní situaci.

\footnotetext{
14i Bliže viz P. K rafl, Legátská statuta pro Polsko a provinciální statuta Hnězdna. o. c.

${ }^{141} K D W$ I., č. 423 , s. 375 , čl. 11.

${ }_{142}$ Statuty synodalne wieluisko-kaliskie, s. 2-3, 10.

${ }_{143}$,Multae etiam constitutiones in eadem synodo (to jest 1257) fuerant ordinatae, quae in ecclesiis cathedralibus reservantur reconditae." $P D P$ II., s. 581 - 582.

${ }^{144}$ SPPP I., s. 414-415; KDW III., č. 1787, s. 505-506. W. A bra h a m, Przyczynki do dziejów kościola i prawa kościelnego w Polsce, Sprawozdania Towarzystwa Naukowcgo we Lwowic, 8, 1928 , č. 1, s. 13-15, referát č. 352.

${ }^{145} A C I E$ I., č. 1529, s. 324.
} 


\section{Katalog prokázaných provinciálních synod hnězdenské církevní provincíe do počátku 16. století}

- rok, denní datum (denní svátek), místo konání, svolavatel, informace o vydaných statutech

A.

- kolem 1206, Henryk Kietlicz

- 1210, 29. července, Borzykow (Borzykowa ?), Henryk Kietlicz

- 1215 či před 1215, Wolborz, Henryk Kietlicz

- ??, Witow

- ??, "Chelou" ?

- ?? kolem 1217, Kamień, Henryk Kietlicz, statuta

- 1226, ? - kostel sv. Bla•eje, Wincenty z Niałka

- 1233, 3. - 6. července, Sieradz, Pełka, statuta

- 1257, 14. ŕ́jna (sv. Kalixta), Leczyca, Pełka, nedochovaná statuta

- 1258, 17. zár̆í (sv. Lamberta), Wrocieryż, Januš

- 1262, 17. záŕí (sv. Lamberta) - 19. záríí, Sieradz, Januš, statuta

- 1267,16 .ŕína, Dankow, Januš

- 1269,16 . ŕína, Pajęczno, Januš

- 1270, 20. záŕí, Sieradz, Januš

- 1285,6 . ledna (Zjevení Páně), Lęczyca, Jakub Świnka, statuta

- 1287,26 . ř́jna (ten den se konalo třetí sezeni), Lęczyca, Jakub Świnka

- 1290,14 . ŕjina (sv. Kalixta), Hnězdno, Jakub Świnka

- 1298, Hnězdno, Jakub Świnka

- 1306, před 20. červencem, Jakub Świnka

- 1309, před 2. květnem, Hnězdno, Jakub Świnka B.

- 1326, 19. února, Uniejow, Janisław, statuta

- 1357, 8.-10. ledna, Kališ, Jarosław Skotnicki, statuta a inkorporace (,Synodyk")

C.

- 1406, 18.-20. květen, Kališ, Mikołaj Kurowski, statuta

- 1409, 27. ledna (neděle po obrácení sv. Pavla), Kališ, Mikołaj Kurowski

- 1414, před 30. záŕím, Uniejow, Mikołaj Trąba

- 1420, svolána na 13. leden (oktáva Zjevení Páně) a zřejmě dny následující, Wieluń, 15. zárí (oktáva Narození Panny Marie) - 25. záŕi, Kališ, Mikołaj Trąba, statuta

- 1422, svolána na 24. srpna (sv. Bartoloměje), Lęczyca, Mikołaj Trąba

- 1425,6 . května, Lęczyca, Wojciech Jastrzębiec před 19. březnem 1430 (včetně), Lęczyca, Wojciech Jastrzębiec 
- 1431, po 17. listopadu, Uniejow ?, Wojciech Jastrzębiec

- 1433, po 10. březnu, Lęczyca, Wojciech Jastrzębiec

- 1435, 26. května, Lęczyca, Wojciech Jastrzębiec

- 1440, 23. dubna (sv. Vojtěcha) - 27. dubna, Lęczyca, Wincenty Kot

- 1440, svolána na 15. ŕjina (sv. Hedviky), Lęczyca, Wincenty Kot

- 1441, 8. května (sv. Stanislava), Lęczyca, Wincenty Kot

- 1442, svolána na 23. dubna (sv. Vojtěcha), Piotrkow, Wincenty Kot D.

- 1455, Lęczyca, Jan VI. Sprowski

- 1457, po 3. listopadu, ?, Jan VI. Sprowski

- 1459,17 . června (neděle po sv. Vítu), Lęczyca, Jan VI. Sprowski, statuta

- 1462, 5. záŕí, Kališ, Jan VI. Sprowski

- 1463, před 15. dubnem, Lęczyca, Jan VI. Sprowski

- ? 1464, 11. března (neděle Letare), Lęczyca, Jan VI. Sprowski

- 1464, někdy mezi 5. říjnem a 17. prosincem, Wolborz, Jan VII. Gruszczyński

- 1466, 20. - 22. ledna, Lęczyca, Jan VII. Gruszczyński

- 1469, 12. března (sv. Anežky), Lęczyca, Jan VII. Gruszczyński

- 1472, svolána na 14. dubna (sv. Tiburcia a Valeriána), Lęczyca, Jan VII. Gruszczyński

- ? 1473, svolána na 3. leden, Lęczyca, Jan VII. Gruszczyński

- ? 1474, Lęczyca ? Hnězdno ?, administrátor Uriel Górka? Jakub ze Sienny?

- 1475 , svolána na 22 . ledna (neděle Septuagesima), Jakub ze Sienny

- ? 1476, po 21. řijnu, Lęczyca, Jakub ze Sienny

- 1480, 27. února (neděle Reminiscere), Lęczyca, Jakub ze Sienny

- 1485, 20. ledna - 22. leden, Piotrkow, Zbigniew Oleśnicki, statuta

- ? 1486, svolána na 5. března (neděle Letare), Kłodawa, Zbigniew Oleśnicki

- 1487, svolána na 17. srpna (oktáva sv. Vavřince), Lęczyca, Zbigniew Oleśnicki

- 1489, 14. ř́jna (sv. Kalixta) - 15. října, Lęczyca, Zbigniew Oleśnicki

- 1496, svolána na 13. července (sv. Markéty), Lęczyca, Fryderyk Jagiellończyk

- 1497, ? 13. července (sv. Markéty), Kłodawa, Fryderyk Jagiellończyk

- 1499, 17. únor (neděle Invocavit), Lęczyca, Fryderyk Jagiellończyk

- 1501, ? 22. duben, Koło nebo ? 29. duben - 1. květen, Lęczyca, Fryderyk Jagiellończyk

- 1503, 21. leden (sv. Anežky), Lęczyca, lvovský arcibiskup Ondřej Boryszewski, statuta 


\section{SYNODY PROWINCJONALNE GNIEŹNIEŃSKIEJ PROWINCJI KOŚCIELNEJ DO POCZATKU XVI WIEKU}

Bardzo ważną instytucją prawa kanonicznego $\mathrm{w}$ średniowieczu był synod prowincjonalny. Było to zebranie biskupów należących do pewnej prowincji, prokuratorów nieobecnych biskupów oraz następnych prelatów (opaci i przełożeni zakonów, kapituły katedralne oraz kolegiackie, a nawet inni duchowni). Odbywały się pod przewodnictwem metropolity. W statutach swoich usiłowaly one rozwiązywać biężące zagadnienia życia kościelnego, dostosowując jego formy organizacyjne do powszechnych zasad kanonicznych (ustawodawstwo papieskie, ustawodawstwo soborów powszechnych, synodów legackich). W Polsce było życie synodalne na poziomie prowincjonalnym bardzo bogate. Celem pracy jest podsumowanie problematyki synodów prowincjonalnych gnieźnieńskiej prowincji kościelnej do początku XVI wieku. Dążeniem bylo podanie wyliczenia wszystkich synodów razem $\mathrm{z}$ odsyłaczami do źródeł. Ze względu na znaczenie legackich statutów dla ustawodawstwa prowincji kościelnej artykuł informuje także o najważniejszych z nich. $Z$ licznych statutów prowincji gnieźnieńskiej dadzą się zestawić tylko drobne fragmenty postanowień. Warto podkreślić niezależność instytutu synodu prowincjonalnego $\mathrm{w}$ Polsce od organizacji państwowej.

Wspólne zjazdy episkopatu (w XIII stuleciu) i synody prowincjonalne, stały się instrumentem uzgadniania stanowiska biskupów $w$ ich polityce $w$ stosunku do książat dzielnicowych, jak i w sprawach wewnattrzkościelnych. W okresie rozbicia dzielnicowego biskupi wystapili w r. 1180 na zjeździe łęczyckim jako samodzielna grupa z postulatami zniesienia uciążliwych dla kościoła zwyczajów i praktyk. Henryk Kietlicz przy pomocy synodów prowincjonalnych pragnął życie kościoła w Polsce dostosować do norm kościelnego prawa powszechnego. W r. 1210 obradował w Borzykowej synod prowincjonalny równolegle ze zjazdem książąt. Przedtem jednak, chyba r. 1206, mamy wzmiankę o synodzie zwołanym przez metropolitę niezależnie od książąt w związku ze sporem kościelno-politycznym. Później ogłosił arcybiskup Kietlicz wraz z wszystkimi biskupami konstytucje w Kamieniu (około r. 1217). We wstępie do uchwal synodalnych z r. 1233 arcybiskup Pełka zaznaczył, że ogłaszając nowe konstytucje nawiązuje do wydanych już statutów swych poprzedników. Problemy polityczne i gospodarcze poruszał na swych częstych synodach prowincjonalnych arcybiskup Jakub Świnka. W XIII stuleciu jest bardzo problematyczne odróżnienie zjazdów biskupskich i synodów prowincjonalnych.

Urzędowym zestawieniem praw partykularnych ogłoszonych przez metropolitę gnieźnieńskiego był „Synodyk“ Jarosława (1357). Epokowe znaczenie w rozwoju polskiej kodyfikacji prawa partykularnego miał zbiór prymasa Mikołaja Trąby ogłoszony $\mathrm{w} \mathrm{r}$. 1420. Objął on z upoważnienia papieskiego również i statuty legackie oraz podał wyczerpująco całość prawa kanonicznego obowiązującego w Polsce. Dotychczasowe 
ustawodawstwo partykularne zostało zreformowane i ułożone w organicznie związana całość według porządku Dekretałów. W stuleciu XIV synody prowincjonalne nie były liczne, w stuleciu XV były zwoływane bardzo często. W drugiej połowe 15 stulecia odbywały się synody mające na celu uchwalenie podatków płaconych przez kler.

Obrady synodalne toczyły się zwyczajnie przez dni kilka. W Polsce nie było ustalonej miejscowości, w której by były zwoływane synody prowincjonalne. Tylko dwa synody prowincjonalne zwołane zostały w Gnieźnie. Wszystkie zaś inne odbywały się w różnych miejscowościach: w Borzykowej, Wolborzu, Kamieniu, Lęczycy, Sieradzu, Wrocieryżu, Dankowie, Pajęcznie, Uniejowie, Kaliszu, Wieluniu, Piotrkowie, Kłodawie, Kole; niektóre odbyły się w miejscowościach nieznanych. Oceniając, czy znane zebranie miało lub nie miało charakteru synodu prowincjonalnego, autor kieruje się zasadą krytycznego podejścia do źrodeł. Za prowincjonalne synody uważa te tylko zgromadzenia, które $w$ źrodłach są traktowane jako synody prowincjonalne i jednocześnie mają charakter synodu. Zgromadzenia w roku 1356 i 1402 były w rzeczywistości sejmami. Nie istnieją dowody w źrodłach, które by potwierdzały odbywanie się w r. 1423.

\section{GNIEZNO PROVINCIAL SYNODS UP TO THE BEGINNING OF THE SIXTEENTH CENTURY}

It was relatively early that the archbishops of Gniezno began to convoce provincial synods - the oldest dated assembly which is marked in the sources as a provincial synod took place as early as in 1210 . But even before this synod another provincial synod took place in 1206 (?). In the beginning, i. e. in the thirteenth century, it is important to distinguish clearly between bishops' conventions, or colloquia, and provincial synods. The first statutes backed up with evidence are the statutes issued by archbishop Henryk Kietlicz around 1217 in Kamien. Another important archbishop was Pełka (Fulko, 1232 - 1258). Two statutes issued by this metropolitan are still preserved. An important role in the system of provincial legislation was played by legates' synods and the legates' statutes which were proclaimed at them. A number of provincial synods was summoned by the archbishop of Gniezno Jakub Swinka (1285, $1287,1290,1298,1306,1309$ ). Several not dated fragments of statutes originate from his time. In the fourteenth century the situation changes - the only two provincial synods that we know of are the synods of Janisław (1326) and Jarosław Bogoria Skotnicki (1357). „Synodyk“, the first attempt at codification of the legislation of Gniezno church province, comes from Skotnicki's synod. We cannot agree with referring to the assembly at Krakow from 1356 as to a provincial synod. Similarly, the „convencio generalis" in Lęczyca in 1402 could not have been a provincial synod. Thus the first reliably proved provincial synod of the fifteenth century is the synod of Mikolaj 
Kurowski from 1406. The statutes issued at this synod include ruling about regular summoning of provincial synods in three-year intervals. In 1420 at a provincial synod in Kalisz the archbishop Mikołaj Trąba proclaimed the codification of particular church law. Later this codification was promulgated also in the Lwów (Lemberg) church province. Its exceptionality, extensive character and its structure, which imitates the sequence of titles of the canon law collections, predestined this codification to become the basic code of law of the Polish church. The frequent and numerous synods of the fifteenth century became a means of ratifying the contributions of the clergy to the sovereign, especially in the second half of the century. The main sources of information about the synods are no longer statutes, i. e. papers issued at the synods, or chroniclers' and annalists' mentioning of the synods, but the documents of cathedral chapters of the Polish dioceses. It is interesting to note that Prague statute „Crescente cottidie“ from October, 18th 1385 originated in the Polish legislation. 